\title{
NASKAH AKADEMIK
}

\author{
RANCANGAN PERATURAN DAERAH \\ TENTANG \\ KEUANGAN DESA
}

2018 


\section{KATA PENGANTAR}

Puji dan syukur kita panjatkan kehadirat Allah SWT atas rahmat dan karunia-Nya serta taufiq dan hidayah-Nya, sehingga naskah akademik Peraturan Daerah Tentang Pengelolaan Keuangan Desa dapat kami selesaikan.

Gagasan untuk menyusun naskah akademik ini muncul dari Dinas Pemberdayaan Masyarakat dan Pemerintah Desa (DPMPD) Kabupaten ..... untuk merumuskan tatanan masyarakat guna terwujudnya suasana yang kondusif menuju tercapainya kesejahteraan dan ketentraman hidup bermasyarakat.

Dengan tersususnya naskah akademik, diharapkan dapat dijadikan sebagai acuan bagi pengambil keputusan Pemerintah Daerah Kabupaten .... dalam upaya mengajak dan melakukan pembinaan pada individu, maupun kelompok masyarakat.

Kami menyadari sepenuhnya, walaupun telah bekerja keras melakukan yang terbaik dalam penyusunan naskah akademik ini, namun tentu saja masih terdapat kelemahan dan kekurangan bahkan mungkin ada kesalahan dalam penyajian tulisan ini. Untuk itu, koreksi dan masukan sangat kami harapkan, guna penyempurnaan naskah akademik ini.

Akhirnya dalam kesempatan ini, kami menyampaikan ucapan terima kasih kepada berbagai pihak yang telah turut serta membantu dalam memberikan kontribusi pemikiran, perhatian dan bantuannya terhadap penyelesaian serta penyusunan naskah akademik untuk Peraturan Daerah Tentang Pengelolaan Keuangan Desa semoga bermanfaat.

Februari 2018 


\section{DAFTAR ISI}

Halaman Judul

Kata Pengantar

Daftar Isi

\section{BAB I PENDAHULUAN}
A. Latar Belakang 1
B. Identifikasi Masalah ........................................................................................ 3

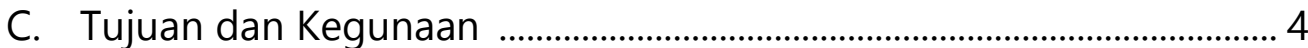

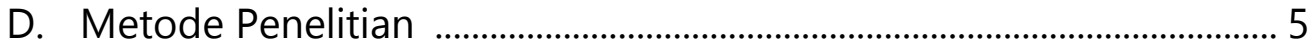

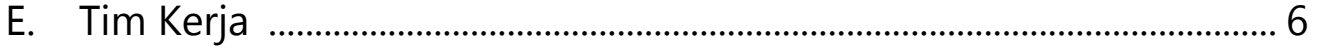

\section{BAB II KAJIAN TEORITIK DAN PRATEK EMPIRIK}
A. Kajian Teoritik 7
B. Kajian Asas/Prinsip ..................................................................................... 19
C. Praktek Keuangan Desa .............................................................................. 22
D. Dampak Pembatasan ...................................................................................... 25
E. Dampak Pembebanan Keuangan Daerah ................................................. 25
F. Dampak Positif ............................................................................................ 26
G. Dampak Negatif ........................................................................................... 27

BAB III ANALISIS DAN EFALUASI PERATURAN PERUNDANGUNDANGAN.

BAB IV LANDASAN FILOSOFIS, YURIDIS, DAN SOSIOLOGIS
A. Landasan Filosofis 52
B. Landasan Yuridis 55
C. Landasan Sosiologis 61

BAB V JANGKAUAN ARAH PENGATURAN, DAN RUANG LINGKUP MATERI MUATAN UNDANG-UNDANG
A. Sasaran 66

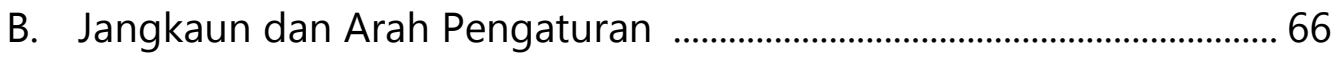
C. Ruang Lingkup Muatan Materi Undang-Undang …………………….... 66

\section{BAB VI PENUTUP}
A. Kesimpulan 70

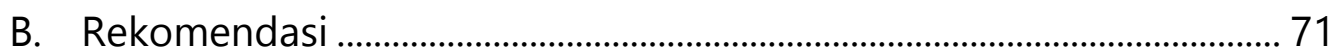
Lampiran Konsep Awal Rancangan Undang-Undang ....................................... 72 


\section{BAB I \\ PENDAHULUAN}

\section{A. Latar Belakang}

Undang-undang Nomor 22 Tahun 1999 dan Undang-undang Nomor 25 Tahun 1999 yang telah disempurnakan dengan Undangundang Nomor 32 Tahun 2004 dan Undang-undang Nomor 33 Tahun 2004 telah mengubah hubungan antara pemerintah pusat dan daerah. Dua uUdang-undang ini digunakan sebagai dasar hukum proses desentralisasi di Indonesia dengan memberikan peranan yang sangat penting kepada pemerintah lokal (kabupaten/kota).

Sejak kedua peraturan tersebut diundangkan pemerintah Indonesia telah berubah secara drastis dari pemerintah yang tersentralisasi menjadi pemerintah yang sangat terdesentralisasi. Berkah otonomi dirasakan mulai dari provinsi, kabupaten/kota sampai ke desa. Seiring dengan berlakunya otonomi daerah telah terjadi reformasi dibidang keuangan negara. Tanggal 5 April 2003 menjadi tonggak sejarah pengelolaan keuangan negara di Indonesia. Pada tanggal tersebut pemerintah Indonesia telah mengundangkan sebuah Undang-undang fenomenal yaitu Undang-undang Nomor 17 Tahun 2003 Tentang Keuangan Negara. Undang-undang ini menggantikan Undang-undang dan peraturan-peraturan produk kolonial Hindia Belanda yaitu;

1). Indische Comptabiliteitswet (ICW), Staatsblad Tahun 1925 Nomor 448 sebagaimana telah beberapa kali diubah, terakhir dengan Undang-undang Nomor 9 Tahun 1968 (Lembaran Negara Republik Indonesia Tahun 1968 Nomor 53, Tambahan Lembaran Negara. Nomor 2860l ;

2) Indische Bedrijvenwet (IBW) Stbl. 1927 NO, 419 jo. Stbl. 1936 NO. 445 ;

3) Reglement voor he Administratief Beheer (RAB) Stbl. 1933 Nomor 381. 
Beberapa bulan kemudian dua paket undang-undang lainnya, yang merupakan bagian dari 3 paket undang-undang di bidang keuangan negara yang telah lama disiapkan, diundangkan oleh pemerintah yaitu Undang-undang Nomor 1 Tahun 2004 Tentang Perbendaharaan, Undang-undang Nomor 15 Tahun 2004 Tentang Pemeriksaan Pengelolaan dan Tanggung Jawab Keuangan Negara.

Melalui ketiga undang-undang tersebut, paling tidak pemerintah telah berupaya untuk memperbaiki kelemahankelemahan yang terjadi dalam pengelolaan keuangan pemerintah selama ini yaitu: kelemahan di bidang perencanaan dan penganggaran, kelemahan di bidang perbendaharaan, dan kelemahan di bidang pemeriksaan/audit ${ }^{1}$.

Lebih lanjut pemerintah mengeluarkan Peraturan Menteri Dalam Negeri Nomor 37 Tahun 2007 Tentang Pedoman Pengelolaan Keuangan Desa. Permendagri tersebut bertujuan untuk memudahkan dalam pelaksanaan pengelolaan keuangan desa, sehingga tidak menimbulkan multi tafsir dalam penerapannya. Dengan demikian desa dapat mewujudkan pengelolaan keuangan yang efektif dan efisien. Disamping itu diharapkan dapat diwujudkan tata kelola pemerintahan desa yang baik, yang memiliki tiga pilar utama yaitu transparansi, akuntabilitas dan partisipatif.

Di Kabupaten ....., sebelumnya telah ada Peraturan Daerah Nomor 32 Tahun 2007 Tentang Keuangan Desa. Regulasi ini merupakan turunan dari Peraturan Pemerintah Nomor 72 Tahun 2005 Tentang Desa yang posisinya telah digantikan dengan Peraturan Pemerintah Nomor 43 Tahun 2014 Tentang Peraturan Pelaksanaan Undang-Undang Nomor 6 Tahun 2014 tentang Desa. Pergantian regulasi tentang desa mengharuskan bagi Pemerintah Daerah khususnya Kabupaten ..... untuk segera melakukan

Taufik, Taufeni. Pengelolaan Keuangan Desa Dalam Sistem Keuangan Negara Republik Indonesia. Akuntansi Fakultas Ekonomi Universitas Riau

2 Naskah Akademik Rancangan Undang-undang Peraturan Daerah Keuangan Desa 
beberapa penyesuaian untuk menghindari terjadinya kesimpangsiuran informasi mengenai pengelolaan keuangan desa.

Dalam rangka menjawab berbagai persoalan diatas, salah satu strategi yang sangat perlu dan mendesak adalah perlu segera menyusun sebuah rancangan Peraturan Daerah tentang Keuangan Desa untuk menggantikan Peraturan Daerah sebelumnya yaitu Peraturan Daerah Nomor 32 Tahun 2007 Tentang Keuangan desa, karena beberapa kebijakan tentang Keuangan Desa sudah harus menyesuaikan dengan Peraturan Perundang-undangan yang baru terkait badan permusyawaratan desa di Kabupaten ......

\section{B. Identifikasi Masalah}

Perubahan tatanan hukum tentang desa serta penataan pengelolaan keuangan desa yang diikuti dengan perubahan sosial yang terjadi pada masyarakat di Kabupaten ..... merupakan kondisi masyarakat yang mengalami berbagai pergeseran tatanan kehidupan sosial politik, konsekuensi yang harus dihadapi yaitu terjadinya perubahan pola pikir, pola tindak sehingga kondisi masyarakat menjadi semakin rentan terhadap konflik, maka yang perlu diidentifikasi dalam kajian ini adalah bagaimana upaya Pemerintah Daerah untuk mewujudkan Kabupaten ..... yang sejahtera melalui pengaturan hukum terhadap pengeloaan keuangan desa.

- $\quad$ Apa kriteria aturan keuangan desa yang dibatasi dan terhadap siapa pembatasan tersebut diberlakukan/diterapkan?

- Permasalahan-permasalahan apa yang dihadapi dalam kehidupan berbangsa, bernegara dan, sehingga diperlukan adanya pengaturan mengenai keuangan desa?

- Apa argumentasi filosofis, sosiologis dan yuridis mengenai perlunya pengaturan keuangan desa? 
- Apa dampak sosial, ekonomi, dan budaya yang harus diperhatikan apabila ketentuan mengenai keuangan desa?

- Apa sasaran, arah dan jangkauan serta ruang lingkup pengaturan keuangan desa?

- Bagaimanakah sanksi terhadap setiap orang yang melanggar ketentuan pengelolaan keuangan desa?

\section{Tujuan dan Kegunaan}

\section{Tujuan Penyusunan Naskah Akademik meliputi :}

1. Merumuskan kriteria keuangan desa yang harus dibatasi dan terhadap siapa pembatasan ini diterapkan.

2. Menggambarkan permasalahan-permasalahan yang dihadapi dalam kehidupan berbangsa, bernegara dan bermasyarakat, yang penyelesaiannya memerlukan adanya pengaturan mengenai keuangan desa.

3. Menguraikan argumentasi filosofis, sosiologis dan yuridis mengenai perlunya pengaturan keuangan desa.

4. Menguraikan dampak sosial, ekonomi, dan budaya yang harus diperhatikan apabila ketentuan mengenai keuangan desa.

5. Mengelaborasi sasaran, arah dan jangkauan serta ruang lingkup pengaturan keuangan desa.

6. Menguraikan sanksi terhadap setiap orang yang melanggar ketentuan keuangan desa.

7. Menentukan instansi yang memiliki kewenangan untuk melakukan pengawasan keuangan desa.

\section{Kegunaan Penyusunan Naskah Akademik}

Penyusunan naskah akademik ini berguna sebagai bahan acuan dalam pengambilan kebijakan masyarakat tentang keuangan desa di Kabupaten ..... sebagai bahan pendukung proses harmonisasi serta 
sebagai persyaratan dalam pengajuan Prioritas Tahunan Program Legislasi Daerah (Prolegda).

\section{Metode Penelitian}

Metode pendekatan yang digunakan dalam penyusunan naskah akademik ini adalah metode yuridis normatif atau penelitian hukum kepustakaan. Sejalan dengan itu, maka sumber penelitian hukum berupa bahan-bahan hukum (primer, sekunder dan tersier) seperti peraturan dasar, peraturan perundang-undangan, tulisan-tulisan, literatur, serta hasil penelitian yang akan dipergunakan.

Bahan-bahan hukum primer terdiri dari perundang-undangan, catatan-catatan resmi atau risalah dalam pembuatan Perundangundangan dan putusan-putusan hakim. Sedangkan bahan-bahan sekunder berupa semua publikasi tentang hukum yang bukan merupakan dokumen-dokumen resmi. Publikasi tentang hukum meliputi buku-buku teks, kamus-kamus hukum, jurnal-jurnal hukum, dan komentar komentar atas putusan pengadilan (bahanbahan tersier) ${ }^{2}$.

Berdasarkan metode tersebut, data dan informasi yang diperoleh akan disusun secara deskriptif dan sistimatis untuk memudahkan bagi pengambilan kebijakan dan membantu perumusan norma oleh perancang Perundang-undangan (legal drafter). Penyusunan naskah akademik tentang badan permusyawaratan desa ini juga didukung oleh studi perbandingan dengan mengambil bahan hukum sekunder yang tidak hanya dari Kabupaten ....., tetapi juga dari daerah lain.

Dalam memperkaya substansi, maka naskah akademik tentang keuangan desa akan menggunakan analisis kualitatif dan kuantitatif dari berbagai narasumber yang terkait dengan penyelenggaraan.

${ }^{2}$ Peter Mahmud Marzuki, Penelitian Hukum, Penerbit Kencana, Tahun 2007, hlm. 141 
E. . 


\section{BAB II \\ KAJIAN TEORITIK DAN PRAKTEK EMPIRIK}

\section{A. Kajian Teoritik}

Dalam rangka mendukung terwujudnya tata kelola yang baik (good governace) dalam penyelenggaraan desa, pengelolaan keuangan desa dilakukan berdasarkan prinsip tata kelola yaitu transparan, akuntabel dan partisipatif serta dilakukan dengan tertib dan disiplin anggaran. Pengelolaan keuangan desa, dikelola dalam masa 1 (satu) tahun anggaran yakni mulai tanggal 1 Januari sampai dengan tanggal 31 Desember. Tentang Pedoman Pengelolaan Keuangan Daerah, dikatakan transparan adalah prinsip keterbukaan yang memungkinkan masyarakat untuk mengetahui dan mendapatkan akses informasi seluas-luasnya tentang keuangan daerah. Dengan adanya transparansi menjamin akses atau kebebasan bagi setiap orang untuk memperoleh informasi tentang penyelenggaraan pemerintahan, yakni informasi tentang kebijakan, proses pembuatan dan pelaksanannya, serta hasil-hasil yang dicapai. Transparansi yakni adanya kebijakan terbuka bagi pengawasan, sedangkan yang dimaksud dengan informasi adalah informasi mengenai setiap aspek kebijakan pemerintah yang dapat dijangkau oleh publik. Keterbukaan informasi diharapkan akan menghasilkan persaingan politik yang sehat, toleran dan kebijakan dibuat berdasarkan pada preferensi publik.

Pengelolaan keuangan desa adalah keseluruhan kegiatan yang meliputi perencanaan, pelaksanaan, penatausahaan, pelaporan, dan pertanggungjawaban keuangan desa. Penyelenggaraan kewenangan Desa berdasarkan hak asal usul dan kewenangan lokal berskala desa didanai oleh APBDesa. Penyelenggaraan kewenangan lokal berskala desa selain didanai oleh APB Desa, juga dapat didanai oleh anggaran pendapatan dan belanja negara dan anggaran 
pendapatan dan belanja daerah. Penyelenggaraan kewenangan desa yang ditugaskan oleh pemerintah didanai oleh anggaran pendapatan dan belanja negara. Dana anggaran pendapatan dan belanja negara dialokasikan pada bagian anggaran kementerian/lembaga dan disalurkan melalui satuan kerja perangkat daerah kabupaten/kota. Penyelenggaraan kewenangan desa yang ditugaskan oleh pemerintah daerah didanai oleh anggaran pendapatan dan belanja daerah. Seluruh pendapatan desa diterima dan disalurkan melalui rekening kas desa dan penggunaannya ditetapkan dalam APB Desa. Pencairan dana dalam rekening kas desa ditandatangani oleh kepala desa dan bendahara desa. Pengelolaan keuangan desa meliput ${ }^{3}$ :

1. Perencanaan

2. Pelaksanaan

3. Penatausahaan

4. Pelaporan

5. Pertanggungjawaban.

Perencanaan pembangunan desa meliputi RPJM Desa dan RKP Desa yang disusun secara berjangka dan ditetapkan dengan Peraturan Desa. Rencana Pembangunan Jangka Menengah Desa (RPJM Desa) untuk jangka waktu 6 (enam) tahun sedangkan Rencana Pembangunan Tahunan Desa atau yang disebut Rencana Kerja Pemerintah Desa (RKP Desa) untuk jangka waktu 1 (satu) tahun. RKP Desa merupakan penjabaran dari Rencana Pembangunan Jangka Menengah Desa. Perencanaan pembangunan desa disusun berdasarkan hasil kesepakatan dalam musyawarah desa yang pelaksanaannya paling lambat pada bulan Juni tahun anggaran berjalan. Pembangunan Jangka Menengah Desa, perencanaan pembangunan desa disusun berdasarkan hasil kesepakatan dalam

${ }^{3}$ BPKP, 2015. Petunjuk Pelaksanaan Bimbingan dan Konsultasi Pengelolaan Keuangan Desa. Tim penyusun: Deputi Bidang Pengawasan Penyelenggaraan Keuangan Daerah. 
musyawarah desa yang pelaksanaannya paling lambat pada bulan Juni tahun anggaran berjalan.

Setelah RKP Desa ditetapkan maka dilanjutkan proses penyusunan APB Desa. Rencana Kegiatan dan Rencana Anggaran Biaya yang telah ditetapkan dalam RKP Desa dijadikan pedoman dalam proses penganggarannya. Anggaran Pendapatan dan Belanja Desa (APB Desa) merupakan rencana anggaran keuangan tahunan pemerintah desa yang ditetapkan untuk menyelenggarakan program dan kegiatan yang menjadi kewenangan desa. Proses Penyusunan APB Desa dimulai dengan urutan sebagai berikut:

1. Pelaksana Kegiatan menyampaian usulan anggaran kegiatan kepada Sekretaris Desa berdasarkan RKP Desa yang telah ditetapkan.

2. Sekretaris Desa menyusun rancangan Peraturan Desa tentang APB Desa (RAPB Desa) dan menyampaikan kepada Kepala Desa.

3. Kepala Desa selanjutnya menyampaikan kepada Badan Permusyawaratan Desa untuk dibahas dan disepakati bersama. Rancangan Peraturan Desa tentang APB Desa disepakati bersama paling lambat bulan Oktober tahun berjalan antara Kepala Desa dan BPD.

4. Rancangan Peraturan Desa tentang APB Desa yang telah disepakati bersama sebagaimana selanjutnya disampaikan oleh Kepala Desa kepada Bupati/Walikota melalui camat atau sebutan lain paling lambat 3 (tiga) hari sejak disepakati untuk dievaluasi.

5. Bupati/Walikota menetapkan hasil evaluasi Rancangan APB Desa paling lama 20 (dua puluh) hari kerja sejak diterimanya Rancangan Peraturan Desa tentang APB Desa. Dalam hal Bupati/Walikota tidak memberikan hasil evaluasi dalam batas waktu maka Peraturan Desa tersebut berlaku dengan 
sendirinya. Dalam hal Bupati/Walikota menyatakan hasil evaluasi Rancangan Peraturan Desa tentang APB Desa tidak sesuai dengan kepentingan umum dan peraturan perundangundangan yang lebih tinggi Kepala Desa melakukan penyempurnaan paling lama 7 (tujuh) hari kerja terhitung sejak diterimanya hasil evaluasi. Apabila hasil evaluasi tidak ditindaklanjuti oleh Kepala Desa dan Kepala Desa tetap menetapkan Rancangan Peraturan Desa tentang APB Desa menjadi Peraturan Desa, Bupati/Walikota membatalkan Peraturan Desa dengan Keputusan Bupati/Walikota yang sekaligus menyatakan berlakunya pagu APB Desa tahun anggaran sebelumnya.

6. Peraturan Desa tentang APB Desa ditetapkan paling lambat tanggal 31 Desember tahun anggaran berjalan.

Dalam pelaksanaan keuangan desa, terdapat beberapa prinsip umum yang harus ditaati yang mencakup penerimaan dan pengeluaran. Prinsip itu diantaranya bahwa seluruh penerimaan dan pengeluaran desa dilaksanakan melalui Rekening Kas Desa. Pencairan dana dalam Rekening Kas Desa ditandatangani oleh Kepala Desa dan Bendahara Desa. Namun khusus bagi desa yang belum memiliki pelayanan perbankan di wilayahnya maka pengaturannya lebih lanjut akan ditetapkan oleh pemerintah kabupaten/kota. Dengan pengaturan tersebut, maka pembayaran kepada pihak ketiga secara normatif dilakukan melalui transfer ke rekening bank pihak ketiga.

Penatausahaan Keuangan Desa adalah kegiatan pencatatan yang khususnya dilakukan oleh Bendahara Desa. Bendahara Desa wajib melakukan pencatatan terhadap seluruh transaksi yang ada berupa penerimaan dan pengeluaran. Bendahara Desa melakukan pencatatan secara sistematis dan kronologis atas transaksi-transaksi keuangan yang terjadi. Penatausahaan keuangan desa yang 
dilakukan oleh Bendahara Desa dilakukan dengan cara sederhana, yaitu berupa pembukuan belum menggunakan jurnal akuntansi. Penatausahaan baik penerimaan kas maupun pengeluaran kas, Bendahara Desa menggunakan:
a. Buku Kas Umum
b. Buku Kas Pembantu Pajak
C. Buku Bank
d. Bendahara Desa melakukan pencatatan atas seluruh penerimaan dan pengeluaran dalam Buku Kas Umum untuk yang bersifat tunai. Sedangkan transaksi penerimaan dan pengeluaran yang melalui bank/transfer dicatat dalam Buku Bank. Buku Kas Pembantu Pajak digunakan oleh Bendahara Desa untuk mencatat penerimaan uang yang berasal dari pungutan pajak dan mencatat pengeluaran berupa penyetoran pajak ke kas Negara. Khusus untuk pendapatan dan pembiayaan, terdapat buku pembantu berupa Buku Rincian Pendapatan dan Buku Rincian Pembiayaan.

Dalam melaksanakan tugas, kewenangan, hak, dan kewajibannya dalam pengelolaan keuangan desa, kepala desa memiliki kewajiban untuk menyampaikan laporan. Laporan tersebut bersifat periodik semesteran dan tahunan, yang disampaikan ke Bupati/Walikota dan ada juga yang disampaikan ke BPD. Rincian laporan sebagai berikut: Laporan kepada Bupati/Walikota (melalui (amat):
a. Laporan Semesteran Realiasasi Pelaksanaan APB Desa;
b. Laporan Pertanggungjawaban Realisasi Pelaksanaan APB Desa kepada Bupati/Walikota setiap akhir tahun anggaran.
c. Laporan Realisasi Penggunaan Dana Desa Laporan kepada Badan Permusyawaratan Desa (BPD).


d. Laporan Keterangan Pertanggungjawaban Realisasi

Pelaksanaan APB Desa terdiri dari Pendapatan, Belanja, dan

Pembiayaan.

Laporan Pertanggungjawaban Realisasi Pelaksanaan APB Desa merupakan laporan yang disampaikan secara periodik kepada BPD terhadap pelaksanaan APB Desa yang telah disepakati di awal tahun dalam bentuk Peraturan Desa. Laporan Pertanggungjawaban Realisasi Pelaksanaan APB Desa dilampiri:

a. Format Laporan Pertanggungjawaban Realisasi Pelaksanaan APB Desa Tahun Anggaran berkenaan.

b. Format Laporan Kekayaan Milik Desa per 31 Desember Tahun Anggaran berkenaan.

c. Format Laporan Program Pemerintah dan Pemerintah Daerah yang Masuk ke Desa.

Transparansi menjadi sangat penting bagi pelaksanaan fungsifungsi pemerintah dalam menjalankan mandat dari rakyat. Mengingat pemerintah memiliki kewenangan mengambil berbagai keputusan penting yang berdampak bagi orang banyak, pemerintah harus menyediakan informasi yang lengkap mengenai apa yang dikerjakannya. Dengan transparansi, kebohongan sulit untuk disembunyikan. Dengan demikian transparansi menjadi instrumen penting yang dapat menyelamatkan uang rakyat dari perbuatan korupsi. Prinsip-prinsip transparansi dapat diukur melalui sejumlah indikator :

1) Mekanisme yang menjamin sistem keterbukaan dan standarisasi dari semua proses-proses pelayanan publik;

2) Mekanisme yang memfasilitasi pertanyaan-pertanyaan publik tentang berbagai kebijakan dan pelayanan publik, maupun proses-proses didalam sektor publik;

3) Mekanisme yang memfasilitasi pelaporan maupun penyebaran informasi maupun penyimpangan tindakan aparat publik 
didalam kegiatan melayani. Keterbukaan pemerintah atas berbagai aspek pelayanan publik, pada akhirnya akan membuat pemerintah menjadi bertanggungjawab kepada semua stakeholders yang berkepentingan dengan proses maupun kegiatan dalam sektor publik ${ }^{4}$.

Akuntabilitas (accountability) adalah kewajiban untuk memberikan pertanggungjawaban atau menjawab dan menerangkan kinerja dan tindakan seseorang badan hukum pimpinan suatu organisasi kepada pihak yang memiliki hak atau berkewanangan untuk meminta keterangan atau pertanggungjawaban. Dalam pelaksanaan akuntabilitas dilingkungan instansi pemerintah, perlu diperhatikan prinsip-prinsip sebagai berikut :

1) Harus ada komitmen dari pimpinan dan seluruh staf instansi untuk melakukan pengelolaan pelaksanaan misi agar akuntabel;

2) Harus merupakan suatu sistem yang dapat menjamin penggunaan sumber-sumber daya secara konsisten dengan peraturan perundang-undangan yang berlaku;

3) Harus dapat menunjukkan tingkat pencapaian tujuan dan sasaran yang telah ditetapkan;

4) Harus berorientasi pada pencapaian visi dan misi serta hasil dan manfaat yang diperoleh;

5) Harus jujur, objektif, transparan dan inovatif sebagai katalisator perubahan manajemen instansi pemerintah dalam bentuk pemutakhiran metode dan teknik pengukuran kinerja dan penyusunan laporan akuntabilitas ${ }^{5}$.

4 Moedarlis, Fajar Trilaksana. 2016.Sistem Akuntabilitas Keuangan Desa. Fakultas Ilmu Sosial Dan Ilmu Politik Universitas Muhammadiyah Yogyakarta

5 LAN dan BPKP, Akuntabilitas dan Good Governance, Modul 1 dari 5 Modul Sosialisasi Sistem Akuntabilitas Kinerja Instansi Pemerintah, Penerbit LAN, Jakarta

13 Naskah Akademik Rancangan Undang-undang Peraturan Daerah Keuangan Desa 
Sedangkan Partisipasi menurut ${ }^{6}$ adalah setiap warganegara mempunyai suara dalam pembuatan keputusan, baik secara langsung maupun melalui intermediasi institusi legitimasi yang mewakili kepentingannya. Partisipasi ini dibangun atas dasar kebebasan berasosiasi dan berbicara serta berpartisipasi secara konstruktif. Partisipasi masyarakat dalam penentuan kebijakan publik menjadi kekuatan pendorong untuk mempercepat terpenuhinya prinsip akuntabilitas dari penyelenggara pemerintahan di desa.

\section{Pengertian Keuangan dan Aset Desa}

Untuk menjalankan urusan pemerintahan yang menjadi kewenangannya, desa harus mempunyai sumber keuangan agar mampu memberikan pelayanan dan kesejahteraan kepada rakyat di desanya. Keuangan desa menurut Pasal 1 angka 10 Undang-undang Nomor 6 Tahun 2014 adalah semua hak dan kewajiban desa yang dapat dinilai dengan uang serta segala sesuatu berupa uang dan barang yang berhubungan dengan pelaksanaan hak dan kewajiban Desa. Pemberian sumber keuangan kepada desa harus seimbang dengan beban atau urusan pemerintahan yang diserahkan kepada desa.

Keseimbangan sumber keuangan ini merupakan jaminan terselenggaranya urusan pemerintahan yang diserahkan kepada desa, sumber keuangan dapat bersumber dari pajak daerah dan retribusi daerah maupun dari dana perimbangan sebagai konsekwensi dari penyerahan urusan pemerintahan kepada daerah yang diselenggarakan berdasarkan asas otonomi. Selain keuangan desa yang menjadi sumber penyelenggaraan pemerintahan desa, maka aset desa atau kekayaan desa juga merupakan modal sosial sekaligus modal ekonomi yang bisa dijadikan pengungkit kegiatan 
produktif masyarakat. Aset/barang milik daerah adalah semua kekayaan daerah baik yang dibeli atau diperoleh atas beban Anggaran Pendapatan dan Belanja Daerah maupun yang berasal dari perolehan lain yang sah baik yang bergerak maupun yang tidak bergerak beserta bagian-bagiannya atau pun yang merupakan satuan tertentu yang dapat dinilai, dihitung, diukur, atau ditimbang termasuk hewan dan tumbuh-tumbuhan kecuali uang dan suratsurat berharga lainnya ${ }^{7}$.

Secara sederhana pengelolaan kekayaan (aset) daerah meliputi tiga fungsi utama, yaitu :

(1) Adanya perencanaan yang tepat;

(2) Pelaksanaan/pemanfaatan secara efisien dan efektif; dan

(3) Pengawasan (monitoring) ${ }^{8}$.

Namun demikian, hal lain yang tidak kalah pentingnya untuk diperhatikan dari ketiga fungsi yang telah disebutkan di atas adalah berkenaan dengan upaya optimalisasi pengelolaan atau pemanfaataan kekayaan daerah. Untuk itu, diperlukan strategi yang tepat dalam pemanfaatan aset daerah. Sasaran strategis yang harus dicapai dalam kebijakan pengelolaan/pemanfaatan aset daerah antara lain:

(1) Terwujudnya ketertiban administrasi mengenai kekayaan daerah baik menyangkut inventarisasi tanah dan bangunan, sertifikasi kekayaan daerah, penghapusan dan penjualan aset daerah, sistem pelaporan kegiatan tukar menukar, hibah, dan ruislag;

(2) Terciptanya efisiensi dan efektifitas pembangunan aset daerah;

(3) Pengamanan aset daerah; dan

${ }^{7}$ Chabib Soleh dan Heru Rochmansjah, Pengelolaan Keuangan Dan Aset Daerah, Sebuah Pendekatan Struktural Manuju Tata Kelola Pemerintahan Yang Baik, (Fokusmedia, Bandung, 2010), hlm. 158.

${ }^{8}$ Ibid., hlm. 151.

15 Naskah Akademik Rancangan Undang-undang Peraturan Daerah Keuangan Desa 
|

(4) Tersedianya data informasi yang akurat mengenai jumlah kekayaan daerah.

Sedangkan aset desa menurut Pasal 1 angka 11 Undang-undang Nomor 6 Tahun 2014 adalah barang milik desa yang berasal dari kekayaan asli desa, dibeli atau diperoleh atas beban Anggaran Pendapatan dan Belanja Desa atau perolehan hak lainnya yang sah. Dengan demikian maka aset desa dipilah menjadi beberapa kategorial yaitu:

1. Kekayaan asli (the genuine assets) desa, yang dimiliki desa sejak bangunan sosiologis desa hadir. Kekayaan asli desa tersebut antara lain tanah kas desa, hutan adat, wilayah sumber mineral/kekayaan alam, serta berbagai adat istiadat yang memiliki nilai sosial dan nilai ekonomis.

2. Kekayaan desa yang merupakan kekayaan yang direproduksi program pembangunan.

3. Kekayaan desa yang dimiliki desa yang bersumber dari hibah program pemerintahan di atasnya atau harta benda desa yang dibeli desa dengan memanfaatkan alokasi anggaran dari pemerintah.

Difinisi aset desa sebagaimana tercantum dalam Pasal 1 angka (16) tersebut diatas dimaknai sebagai barang milik desa yang berasal dari kekayaan asli desa, dibeli atau diperoleh atas beban Anggaran Pendapatan dan Belanja Desa atau perolehan hak lainnya yang sah. Aset/Kekayaan desa dengan demikian lebih mengerucut kepada pengertian "kebendaan" yang dikelola oleh pemerintah desa. Bukannya segala modal sosial, modal ekologis, modal ekonomis dan sumber daya alam yang dimiliki oleh desa dan bisa digunakan untuk kemakmuran masyarakat desa.

Untuk melaksanakan fungsi dan kewenangannya, desa memiliki sumber keuangan yang diberikan oleh pemerintah melalui hak, wewenang, dan kewajiban daerah otonom untuk mengatur dan 
mengurus sendiri urusan pemerintahan dan kepentingan masyarakat setempat dalam sistem Negara Kesatuan Republik Indonesia. Keuangan Desa sebagaimana telah disebut diatas menurut Pasal 1 angka 10 jo Pasal 71 ayat (1) Undang-undang Nomor 6 Tahun 2014, adalah semua hak dan kewajiban Desa yang dapat dinilai dengan uang serta segala sesuatu berupa uang dan barang yang berhubungan dengan pelaksanaan hak dan kewajiban desa. Hak dan kewajiban tersebut menimbulkan pendapatan, belanja, pembiayaan, dan pengelolaan keuangan desa.

Dengan demikian maka desa memiliki sumber pendapatan yang timbul karena tradisi, pembagian dari pemerintah Kabupaten dan berdasarkan arus pelaksanaan tugas pembantuan, pinjaman dan dari pihak ketiga. Karena itu penyelenggaraan urusan pemerintahan desa yang menjadi kewenangan desa dituangkan dan didanai dari Anggaran Pendapatan dan Belanja Desa (APBDesa). APB Desa terdiri atas bagian Pendapatan Desa, Belanja Desa dan Pembiayaan. Rancangan APB Desa dibahas dalam musyawarah perencanaan pembangunan desa. Kepala Desa bersama BPD menetapkan APBDesa setiap tahun dengan peraturan desa. Penyelenggaraan urusan pemerintah daerah yang diselenggarakan oleh pemerintah desa didanai dari APBD dan Penyelenggaraan urusan pemerintah yang diselenggarakan oleh pemerintah desa didanai dari APBN.

Sumber pendapatan desa menurut Pasal 72 Undang-undang Nomor 6 Tahun 2014 bersumber dari:

a. Pendapatan asli Desa terdiri atas hasil usaha, hasil aset, swadaya dan partisipasi, gotong royong, dan lain-lain pendapatan asli desa;

b. Alokasi Anggaran Pendapatan dan Belanja Negara;

C. Bagian dari hasil pajak daerah dan retribusi daerah Kabupaten/Kota; 
d. Alokasi dana desa yang merupakan bagian dari dana perimbangan yang diterima Kabupaten/Kota;

e. Bantuan keuangan dari Anggaran Pendapatan dan Belanja Daerah Provinsi dan Anggaran Pendapatan dan Belanja Daerah Kabupaten/Kota;

f. Hibah dan sumbangan yang tidak mengikat dari pihak ketiga; dan dengan kata lain pendapatan asli desa merupakan pendapatan yang diterima oleh pemerintah desa atas segala sumber-sumber atau potensi yang ada pada desa yang harus diolah oleh pemerintah desa dalam memperoleh pendapatan desa.

Dalam rangka memaksimalkan pengelolaan keuangan desa, maka desa perlu dibekali dengan pedoman dan petunjuk teknis perencanaan dan pengelolaan keuangan desa. Menurut IRE Yogyakarta, good governance dalam pengelolaan keuangan desa meliputi:

1. Penyusunan APB Desa dilakukan dengan melibatkan partisipasi masyarakat.

2. Informasi tentang keuangan desa secara transparan dapat diperoleh oleh masyarakat.

3. APB Desa disesuaikan dengan kebutuhan desa.

4. Pemerintah Desa bertanggungjawab penuh atas pengelolaan keuangan.

5. Masyarakat baik secara langsung maupun lewat lembaga perwakilan melakukan pengawasan atas pengelolaan keuangan yang dilakukan oleh pemerintah desa.

Terkait pengelolaan terhadap aset desa dalam pengelolaannya terdapat suatu proses, proses melakukan kegiatan ini dimulai dari adanya proses perencanaan, pelaksanaan rencana tersebut, sampai pada pengawasannya. Perencanaan adalah suatu cara bagaimana mencapai tujuan sebaik-baiknya (maximum output) dengan sumber- 
sumber yang ada supaya lebih efisien dan efektif. Perencanaan juga adalah penentu tujuan yang akan dicapai, bagaimana, bilamana, dan oleh siapa. Sedangkan Pelaksanaan untuk pengelolaan kekayaan/aset daerah/desa harus memenuhi prinsip akuntabilitas publik yang harus dipenuhi, antara lain:

1) Akuntabilitas kejujuran dan akuntabilitas hukum,

2) Akuntabilitas proses,

3) Akuntabilitas kebijakan, dan

4) Pengawasan, yaitu suatu proses dimana pimpinan ingin mengetahui hasil pelaksanaan sesuai dengan rencana dan perintah kebijakan yang telah ditentukan ${ }^{9}$

\section{B. Kajian Asas/Prinsip}

1. Asas Manfaat

Suatu Undang-undang perlu juga memperhatikan prinsip atau asas manfaat. Asas manfaat dalam pembentukan suatu Undangundang mengacu kepada pengertian bahwa Undang-undang tersebut memberikan atau membawa manfaat kepada orang banyak. Prinsip atau asas ini lebih dikenal dengan istilah "greatest good for the greatest number of citizens" yang diperkenalkan oleh Jeremy Bentham ${ }^{10}$.

Pembatasan aktifitas pada rancangan undang-undang keuangan desa dengan mengarahkan masyarakat pada kegiatan yang merupakan kebermanfaatan dari apa yang akan diatur dalam peraturan daerah mengenai gerakan yang dilakukan secara bersama-sama dengan tujuan untuk mencapai keharmonisan dalam kehidupan.

${ }^{9}$ Chabib Soleh dan Heru Rochmansjah,Op Cit, 158

10 Jeremy Bentham, An Introduction to the Principles of Morals and Legislation, Batoche Books: Kitchener, ON Canada, 2000, p. 14. 
2. Asas Kepentingan Umum

Asas kepentingan umum merupakan asas yang berdasarkan pada kewenangan negara untuk melindungi dan mengatur masyarakat lebih luas. Dalam hal ini negara dapat menentukan semua keadaan dan peristiwa yang sesuai dengan kepentingan umum.

Tujuan asas kepentingan umum adalah untuk mewujudkan ketertiban dan keamanan seluruh masyarakat. Pengaturan yang berkaitan dengan kepentingan umum tidak berkait dengan apa yang diberikan oleh negara.

Asas kepentingan umum adalah suatu asas yang mendahulukan kebutuhan masyarakat umum dibandingkan dengan kebutuhan masyarakat atau golongan tertentu.

Selanjutnya kepentingan umum juga diuraikan lebih lanjut dalam penjelasan Pasal 49 b Undang-undang Nomor 5 Tahun 1986 tentang Peradilan Tata Usaha Negara yang menyatakan bahwa kepentingan umum adalah "kepentingan bangsa dan Negara dan/atau kepentingan masyarakat bersama dan/atau kepentingan pembangunan, sesuai dengan peraturan PerundangUndangan yang berlaku".

Berdasarkan uraian di atas dapat disimpulkan bahwa pengertian kepentingan umum adalah kepentingan yang harus didahulukan dari kepentingan-kepentingan yang lain dengan tetap memperhatikan proporsi pentingnya dan tetap menghormati kepentingan-kepentingan lain.

Seyogyanya kepentingan umum dalam peraturan perundangundangan tetap dirumuskan secara umum atau luas. Kalau dirumuskan secara rinci atau kasuistis dalam peraturan perundang-undangan penerapannya akan kaku, karena hakim lalu terikat pada rumusan Undang-undang. Rumusan umum oleh pembentuk Undang-undang akan lebih luwes/fleksibel karena 
penerapan atau penafsirannya oleh hakim berdasarkan kebebasannya, dapat secara kasuistis disesuaikan dengan perkembangan masyarakat dan keadaan.

3. Asas Hukum sebagai Alat Rekayasa Sosial

Pada asas ini dijabarkan peran hukum sebagai "sarana rekayasa sosial" atau sarana untuk menentukan arah pembangunan masyarakat yang dikehendaki agar lebih baik. Hukum sebagai sarana perubahan sosial (law as tool of social engineering) menuju kondisi hukum yang lebih baik ini diungkapkan oleh Roscoe Pound.

Dalam Undang-undang ini, penggunaan asas hukum sebagai alat rekayasa sosial sangat penting sebab pembentukan Undangundang keuangan desa adalah upaya mengubah serta memperbaiki kebiasaan masyarakat dari keterbatasan menjadi lebih fleksibel dan berkesinambungan.

Oleh karena itu, sebelum sebuah kebijakan disampaikan ke ruang publik, perlu sosialisasi yang massal agar informasi yang akurat sampai ke masyarakat dan merekonstruksi kesadaran hukum baru ${ }^{11}$. Peran hukum (peraturan perundang-undangan) sebagai sarana rekayasa sosial dalam mengubah gaya bermasyarakat dalam melakukan transaksi penting. Adanya gagasan atas perubahan sosial kearah yang lebih baik dengan cara yang benar dan lebih realistis dapat mendorong keinginan masyarakat untuk berpartisipasi dalam misi atas perubahan sosial tersebut $^{12}$.

11 Joseph Raz, The Concept of A Legal System: An Introduction to the Theory of Legal System, Oxford: Clarendon Press, 1997, p.165. Dalam terminologi Raz, kesadaran hukum dimulai dari sebentuk pengetahuan terlebih dahulu yang menggumpal dalam memori ingatan, sebelum akhirnya mempengaruhi tindakan personal dan bersifat psikologis.

12 Jimly Asshiddiqie, Konstitusi Ekonomi, Kompas Januari 2010, Jakarta, hal 16 


\section{Praktek Pelaksanaan Keuangan Desa}

1. Telah ada ketentuan sebelumnya

- Pasal 18 Ayat (6) Dan Pasal 33 Ayat (1) Undang-Undang Dasar 1945

- Undang-Undang Republik Indonesia Nomor 12 Tahun 2011 Tentang Pembentukan Peraturan Perundang-Undangan

- Undang-Undang Republik Indonesia Nomor 6 Tahun 2014 Tentang Desa

- Undang-Undang Republik Indonesia Nomor 23 Tahun 2014 Tentang Pemerintahan Daerah

- Peraturan Pemerintah Republik Indonesia Nomor 43 Tahun 2014 Tentang Peraturan Pelaksanaan Undang-Undang Nomor 6 Tahun 2014 Tentang Desa

- Peraturan Pemerintah Republik Indonesia Nomor 60 Tahun 2014 Tentang Dana Desa Yang Bersumber Dari Anggaran Pendapatan Dan Belanja Negara

- Peraturan Pemerintah Republik Indonesia Nomor 22 Tahun 2015 Tentang Perubahan Atas Peraturan Pemerintah Nomor 60 Tahun 2014 Tentang Dana Desa Yang Bersumber Dari Anggaran Pendapatan Dan Belanja Negara

- Peraturan Pemerintah Republik Indonesia Nomor 47 Tahun 2015 Tentang Perubahan Atas Peraturan Pemerintah Nomor 43 Tahun 2014 Tentang Peraturan Pelaksanaan Undang-undang Nomor 6 Tahun 2014 Tentang Desa

- Peraturan Menteri Dalam Negeri Republik Indonesia Nomor 113 Tahun 2014 Tentang Pengelolaan Keuangan Desa 
- Peraturan Menteri Desa, Pembangunan Daerah Tertinggal, Dan Transmigrasi Republik Indonesia Nomor 22 Tahun 2016 Tentang Penetapan Prioritas Penggunaan Dana Desa Tahun 2017

2. Pentingnya Sosialisasi peraturan yang mengatur tentang keuangan desa

Sasaran sosialisasi peraturan tentang keuangan desa yakni seluruh masyarakat Kabupaten ..... yang berdomisili pada wilayah pemerintahan Kabupaten ..... dengan orientasi untuk pemanfaatan struktur hukum yang terbarukan. Upaya sosialisasi dilaksanakan untuk menghindar kesalahan dalam menafsir maupun mempraktekkan fungsi dan tujuan keuangan desa itu sendiri di tengah-tengah masyarakat. Strategi sosialisasi yang sekiranya dapat dilakukan lewat media tulis, media sosial ataupun tatap muka, maka dengan demikian diharapkan akan terjadi transformasi informasi serta pengetahuan tentang keuangan desa.

\section{Konsep Keuangan Desa}

Keuangan desa dijelaskan dalam Undang-undang Nomor 6 Tahun 2014 Tentang Desa Pasal 71 ayat 1 yakni semua hak dan kewajiban Desa yang dapat dinilai dengan uang serta segala sesuatu berupa uang dan barang yang berhubungan dengan pelaksanaan hak dan kewajiban Desa. Selanjutnya Pasal 71 Ayat (2) menyebutkan bahwa Hak dan kewajiban menimbulkan pendapatan, belanja, pembiayaan, dan pengelolaan Keuangan Desa ${ }^{13}$.

Peraturan Pemerintah Nomor 47 Tahun 2015 Tentang perubahan atas Peraturan Pemerintah Nomor 43 Tahun 2014 tentang peraturan pelaksanaan Undang-undang Nomor 6 Tahun 2014

${ }^{13}$ Lihat pasal 71 ayat 1 dan 2Undang Undang No 6 Tahun 2014 Tentang Desa

23 Naskah Akademik Rancangan Undang-undang Peraturan Daerah Keuangan Desa 
Tentang Desa pasal 1 ayat 8 dan 9 menjelaskan: Pasal 1 ayat 8 Dana Desa adalah dana yang bersumber dari anggaran pendapatan dan belanja negara yang diperuntukkan bagi desa yang ditransfer melalui anggaran pendapatan dan belanja daerah kabupaten/kota dan digunakan untuk membiayai penyelenggaraan pemerintahan, pelaksanaan pembangunan, pembinaan kemasyarakatan, dan pemberdayaan masyarakat ${ }^{14}$.

Pasal 1 ayat 9 Alokasi Dana Desa, selanjutnya disingkat ADD, adalah dana perimbangan yang diterima kabupaten/kota dalam anggaran pendapatan dan belanja daerah kabupaten/kota setelah dikurangi Dana Alokasi Khusus. Permendagri Nomor 113 Tahun 2014 Tentang Pengelolaan Keuangan Desa Pasal 1 ayat 5. Keuangan Desa adalah semua hak dan kewajiban Desa yang dapat dinilai dengan uang serta segala sesuatu berupa uang dan barang yang berhubungan dengan pelaksanaan hak dan kewajiban Desa.

Prinsip pengeloaan keuangan di desa dalam rangka Good Governance harus mencakup beberapa aspek diantaranya adalah:

1. Aspiratif, dalam pengambilan kebijakan tentang pengelolaan keuangan desa pemerintah desa dan BPD harus mendengar aspirasi dari masyarakat.

2. Partisipatif, dalam pengambilan kebijakan pengelolaan keuangan desa, pemerintah desa harus melibatkan masyarakat.

3. Transparan, masyarakat memperoleh informasi yang cukup tentang APBDes, termasuk program pembangunan,lelang kas desa, bantuan pemerintah dan pungutan ke masyarakat.

${ }^{14}$ Lihat pasal 1 ayat 8 Peraturan Pemerintah Republik Indonesia Nomor 47 tahun 2015 Tentang perubahan atas Peraturan Pemerintah Nomor 43 tahun 2014 ten tang peraturan pelaksanaan Undang-Undang nomor 6 tahun 2014 tentang desa 
4. Akuntabilitas, dalam mengelola keungan desa harus berdasarkan kepala aturan yang berlaku ${ }^{15}$.

\section{Dampak Pembatasan}

1. Aspek Sosial Kemasyarakatan

Pembatasan kesempatan ketika seseorang atau kelompok akan mengembangkan potensi diri pada tingkatan tertentu serta keinginan untuk ikut berperan dan berpartisipasi dalam pembangunan dan pengelolaan keuangan desa mengakibatkan adanya peningkatan atau pertumbuhan usaha untuk mendapatkan legalitas sebagai salah satu bagian dan objektifikasi bahwa yang bersangkutan memiliki kemampuan untuk pengelolaan keuangan desa. Apa yang kemudian menjadi dampak akibat peraturan tersebut merupakan konsekuensi logis sebagai akibat dari pelaksanaan dari peraturan yang telah ditetapkan;

2. Aspek Penegakan Hukum

Penegakan hukum dari ketentuan, dalam hal ini penegakan hukum dalam arti sempit, yaitu upaya aparatur penegak hukum untuk menjamin dan memastikan bahwa suatu aturan hukum berjalan sebagaimana seharusnya, memerlukan pula suatu daya paksa guna memastikan bahwa suatu aturan hukum berjalan sebagaimana mestinya.

\section{E. Dampak Pembebanan Keuangan Daerah}

1. Biaya Penyusunan Undang-undang

Biaya penyusunan Undang-undang yang diperlukan adalah sejak dari penyusunan draft awal Undang-undang Keuangan Desa di Pemerintah Daerah Kabupaten ....., biaya pembahasan antar lembaga, biaya harmonisasi peraturan perundangundangan terkait.

15 Edy Supriadi. Pertanggungjawaban Kepala Desa Dalam Pengelolaan Keuangan Desa Berdasarkan Undang-Undang Nomor 6 Tahun 2014 Tentang Desa. Jurnal IUS (Kajian Hukum dan Keadilan),Vol III | Nomor 8

25 Naskah Akademik Rancangan Undang-undang Peraturan Daerah Keuangan Desa 
2. Biaya Pembahasan Undang-undang

Biaya pembahasan Undang-undang meliputi penggandaan dan penjilidan Naskah Akademik dan Undang-undangnya, biaya pembahasan penyusunan antara pemerintah Daerah Kabupaten ..... dan Dewan Perwakilan Rakyat Daerah Kabupaten ......

3. Biaya Pencetakan Resmi Naskah Undang-undang

Biaya yang diperlukan meliputi biaya editing, pencetakan naskah resmi dalam lembaran Negara dan tambahan lembaran negara, dan pengirimannya ke instansi resmi dan masyarakat.

4. Biaya Sosialisasi Undang-undang

Pengaturan mengenai Keuangan desa merupakan sesuatu yang baru bagi sebagian besar masyarakat, sehingga untuk memasyarakatkannya diperlukan sosialisasi secara gencar dan berkesinambungan. Sosialisasi yang dilakukan harus melalui berbagai sarana media, baik cetak maupun elektronik.

Sosialisasi dilakukan di seluruh wilayah atau daerah otonom, biaya yang dibutuhkan cukup besar karena harus mampu menjangkau daerah-daerah pada lokasi yang sulit untuk diakses.

5. Kelembagaan

Kelembagaan sebaiknya dengan memberikan kewenangan terhadap lembaga yang sudah ada. Akan tetapi yang diperlukan adalah adanya biaya untuk melakukan koordinasi antar lembaga terkait agar jelas peran dan fungsi masing-masing lembaga karena dalam pelaksanaannya peraturan daerah mengenai keuangan desa akan terkait sejak dari pelaksanaan, pengawasannya dan penegakan hukumnya.

\section{F. Dampak Positif}

Secara umum dampak positif yang dapat terjadi dengan adanya Peraturan Daerah Keuangan Desa adalah terciptanya ketertiban dalam administrasi mengenai kekayaan daerah baik menyangkut inventarisasi tanah dan bangunan, sertifikasi kekayaan daerah, penghapusan dan 
penjualan aset daerah, sistem pelaporan kegiatan tukar menukar, hibah, dan ruislag. Selama ini kepemilikan aset desa banyak yang terbengkalai karena tidak mendapat perhatian dari pemerintah desa. Dengan adanya Peraturan Daerah tentang keuangan desa akan memberikan kepastian hukum kepada pemerintah desa untuk menertibkan administrasi aset desa.

Dampak positif berikutnya adalah adanya perencanaan dalam pengelolaan keuangan Desa. Program pembangunan desa akan lebih terarah dengan perencanaan keuangan yang matang. Dalam pelaksanannya akan lebih transparan dengan hadirnya Peraturan Daerah Keuangan Desa.

Aparat pemerintah Desa akan mendapatkan dampak positif dari peraturan Daerah ini yaitu akan mendapatkan pembinaan dalam merencanakan, melaksanakan dan membuat laporan terkait pengeloalaan keuangan desa. Hal ini tentunya akan meningkatkan sumber daya manusia aparat desa dalam hal pengelolaan keuangan.

Secara tidak langsung masyarakat desa juga akan mendapatkan dampak positif dari Peraturan Daerah Keuangan Desa ini yaitu dengan pengelolaan keuangan yang baik akan memberikan dampak pada pembangunan desa yang akan dirasakan masyarakat. Program pembangunan desa akan lebih fokus untuk kesejahteraan masyarakat.

\section{G. Dampak Negatif}

Setiap Peraturan tidak hanya memiliki dampak positif, tetapi juga memiliki dampak negatif bila tidak ada tindakan pencegahan. Adapaun dampak negatif yang dapat timbul adalah untuk tahap awal pelaksanaan akan menimbulkan keterlambatan pelaksanaan oleh karena masih lemahnya sumber daya manusia pada tingkat aparat desa dalam hal pengelolaan keuangan desa yang akan berpengaruh juga pada lambatnya proses pembangunan desa. 
Potensi terjadinya penyelewengan terhadap keuangan dan aset desa terbuka. Hal ini bisa terjadi ketika pemerintah desa telah menertibkan aset dan keuangan desa yang ternyata diketahui cukup besar, membuka peluang bagi aparat desa untuk memanfaatkan aset dan keuangan desa untuk kepentingan pribadi dan kelompok. 


\section{BAB III \\ ANALISIS DAN EVALUASI PERATURAN PERUNDANG-UNDANGAN}

\section{Pasal 18 Ayat (6) Dan Pasal 33 Ayat (1) Undang-Undang Dasar 1945}

Kinerja dibidang pembentukan peraturan perundang-undangan dalam 10 tahun terakhir ini memperlihatkan peningkatan baik secara kualitas maupun kuantitas. Hal ini tidak terlepas dari proses penyusunan pembentukan peraturan perundang-undangan yang makin tertib, terarah, dan terukur, meskipun dari segi waktu masih perlu percepatan tanpa mengurangi kualitas suatu peratuan perundang-undangan. Percepatan penyelesaian suatu produk peraturan perundang-undangan perlu didorong terhadap program pembentukan peraturan perundang-undangan untuk merealisasikan program-program startegis pembangunan.

Penyerahan sebagian besar kewenangan pemerintahan kepada pemerintah daerah, telah menempatkan pemerintah daerah sebagai ujung tombak pembangunan nasional, dalam rangka menciptakan kemakmuran rakyat secara adil dan merata. Dalam kaitan ini peran dan dukungan daerah dalam rangka pelaksanaan pembentukan peraturan perundang-undanagan sangat strategis, khususnya dalam membuat peraturan daerah (Perda) dan peraturan daerah lainnya sesuai dengan ketentuan peraturan perundang-undangan.

Perda sebagai jenis peraturan perundang-undangan nasional memiliki landasan konstitusional dan landasan yuridis dengan diaturnya kedudukan Perda dalam UUD 1945 Pasal 18 ayat (6) yang menyatakan bahwa pemerintah daerah berhak menetapkan peraturan daerah dan peraturan-peraturan lain untuk melaksanakan otonomi daerah dan tugas pembantuan. Dalam kaitan ini, maka sistem hukum nasional memberikan kewenangan atributif kepada daerah untuk menetapkan Perda dan Peraturan lainnya, dan Perda 


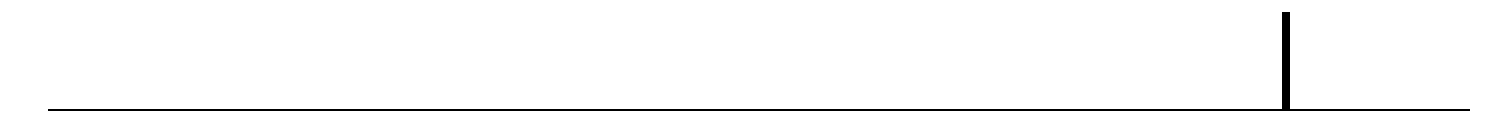

diharapkan dapat mendukung secara sinergis program-program Pemerintah di daerah.

Perda sebagaimana Peraturan perundang-undangan lainnya memiliki fungsi untuk mewujudkan kepastian hukum (rechtszekerheid, legal certainty). Untuk berfungsinya kepastian hukum Peraturan perundang-undanagn harus memenuhi syaratsyarat tertentu antara lain konsisten dalam perumusan dimana dalam Peraturan perundang-undangan yang sama harus terpelihara hubungan sistematik antara kaidah-kaidahnya, kebakuan susunan dan bahasa, dan adanya hubungan harmonisasi antara berbagai peraturan perundang-undangan.

Pengharmonisasian peraturan perundang-undangan memiliki urgensi dalam kaitan dengan asas peraturan perundang-undangan yang lebih rendah tidak boleh bertentangan dengan peraturan perundang-undangan yang lebih tinggi, sehingga hal yang mendasar dalam penyusunan rancangan peraturan daerah adalah kesesuaian dan kesinkronannya dengan peraturan perundang-undangan lainnya. 

asas-asas yang berkaitan dengan "apa"-nya suatu keputusan yang masing-masing disebut asas-asas formal dan asas-asas material.

Berdasarkan pendapat dan ketentuan yang telah disampaikan di atas akan dikemukakan beberapa pandangan dan analisa terhadap Undang-undang Nomor 12 Tahun 2011 Tentang Pembentukan Peraturan Perundang-Undangan (Undang-undang). Secara umum isi Undang-undang dapat dikatakan merupakan keharusan (obligatere) sehingga seluruh ketentuan dalam Undangundang harus dilaksanakan. Jika Undang-undang tidak dilaksanakan maka Undang-undang ini dapat dikatakan tidak berwibawa.

Dalam Pasal 5 Undang-undang disebutkan bahwa dalam membentuk Peraturan Perundang-undangan harus dilakukan berdasarkan pada asas Pembentukan Peraturan Perundangundangan yang baik, yang meliputi:
a. kejelasan tujuan;
b. kelembagaan atau pejabat pembentuk yang tepat;
c. kesesuaian antara jenis, hierarki, dan materi muatan;
d. dapat dilaksanakan;
e. kedayagunaan dan kehasilgunaan;
f. kejelasan rumusan; dan
g. keterbukaan.

Kemudian dalam Pasal 6 ayat (1) Undang-undang disebutkan bahwa materi muatan Peraturan Perundang-undangan harus mencerminkan asas:
a. pengayoman;
b. kemanusiaan;
c. kebangsaan;
d. kekeluargaan;
e. kenusantaraan;
f. bhinneka tunggal ika;
g. keadilan;
h. kesamaan kedudukan dalam hukum dan pemerintahan;
i. ketertiban dan kepastian hukum; dan/atau
j. keseimbangan, keserasian, dan keselarasan.
Selanjutnya dalam Pasal 6 ayat (2) dinyatakan bahwa selain mencerminkan asas sebagaimana dimaksud pada ayat (1), 
Peraturan Perundang-undangan tertentu dapat berisi asas lain sesuai dengan bidang hukum peraturan perundang-undangan yang bersangkutan.

Kedua Pasal tersebut berisi asas-asas formal dan material yang harus dilaksanakan dalam pembentukan setiap peraturan Perundang-undangan di Indonesia. Sebagaimana telah disampaikan isi Undang-undang secara umum dapat dikatakan merupakan keharusan sehingga dalam setiap pembentukan peraturan Perundang-undangan di Indonesia asas-asas tersebut harus ditaati tanpa pengecualian apapun.

Sebagai sebuah Undang-undang yang menjadi peraturan dalam rangka pembentukan peraturan Perundang-undangan dapat dikatakan sudah baik. Jika saja setiap orang yang terlibat dalam pembentukan peraturan Perundang-undangan mau mempelajari dan melaksanakan Undang-undang maka tidak akan mengalami banyak kesulitan lagi terlebih dengan keberadaan lampiran yang sangat mendetail.

\section{Undang-Undang Republik Indonesia Nomor 6 Tahun 2014 Tentang Desa}

Pasal 71

(1) Keuangan Desa adalah semua hak dan kewajiban desa yang dapat dinilai dengan uang serta segala sesuatu berupa uang dan barang yang berhubungan dengan pelaksanaan hak dan kewajiban desa.

(2) Hak dan kewajiban sebagaimana dimaksud pada ayat (1) menimbulkan pendapatan, belanja, pembiayaan, dan pengelolaan keuangan desa.

Pasal 72

(1) Pendapatan desa sebagaimana dimaksud dalam Pasal 71 ayat (2) bersumber dari: 
a. pendapatan asli desa terdiri atas hasil usaha, hasil aset, swadaya dan partisipasi, gotong royong, dan lain-lain pendapatan asli desa;

b. alokasi Anggaran Pendapatan dan Belanja Negara;

C. bagian dari hasil pajak daerah dan retribusi daerah Kabupaten/Kota;

d. alokasi dana desa yang merupakan bagian dari dana perimbangan yang diterima Kabupaten/Kota;

e. bantuan keuangan dari Anggaran Pendapatan dan Belanja Daerah Provinsi dan Anggaran Pendapatan dan Belanja Daerah Kabupaten/Kota;

f. hibah dan sumbangan yang tidak mengikat dari pihak ketiga; dan

g. lain-lain pendapatan desa yang sah

(2) Alokasi anggaran sebagaimana dimaksud pada ayat (1) huruf b bersumber dari belanja pusat dengan mengefektifkan program yang berbasis desa secara merata dan berkeadilan.

(3) Bagian hasil pajak daerah dan retribusi daerah Kabupaten/Kota sebagaimana dimaksud pada ayat (1) huruf $c$ paling sedikit 10\% (sepuluh perseratus) dari pajak dan retribusi daerah.

(4) Alokasi dana desa sebagaimana dimaksud pada ayat (1) huruf d paling sedikit 10\% (sepuluh perseratus) dari dana perimbangan yang diterima Kabupaten/Kota dalam Anggaran Pendapatan dan Belanja Daerah setelah dikurangi Dana Alokasi Khusus.

(5) Dalam rangka pengelolaan Keuangan Desa, Kepala Desa melimpahkan sebagian kewenangan kepada perangkat desa yang ditunjuk.

(6) Bagi Kabupaten/Kota yang tidak memberikan alokasi dana desa sebagaimana dimaksud pada ayat (4), Pemerintah dapat melakukan penundaan dan/atau pemotongan sebesar alokasi 
dana perimbangan setelah dikurangi Dana Alokasi Khusus yang seharusnya disalurkan ke desa.

Pasal 73

(1) Anggaran Pendapatan dan Belanja Desa terdiri atas bagian pendapatan, belanja, dan pembiayaan desa.

(2) Rancangan Anggaran Pendapatan dan Belanja Desa diajukan oleh Kepala Desa dan dimusyawarahkan bersama Badan Permusyawaratan Desa.

(3) Sesuai dengan hasil musyawarah sebagaimana dimaksud pada ayat (2), Kepala Desa menetapkan Anggaran Pendapatan dan Belanja Desa setiap tahun dengan Peraturan Desa.

Pasal 74

(1) Belanja Desa diprioritaskan untuk memenuhi kebutuhan pembangunan yang disepakati dalam musyawarah desa dan sesuai dengan prioritas Pemerintah Daerah Kabupaten/Kota, Pemerintah Daerah Provinsi, dan Pemerintah.

(2) Kebutuhan pembangunan sebagaimana dimaksud pada ayat (1) meliputi, tetapi tidak terbatas pada kebutuhan primer, pelayanan dasar, lingkungan, dan kegiatan pemberdayaan masyarakat desa.

Pasal 75

(1) Kepala Desa adalah pemegang kekuasaan pengelolaan Keuangan Desa.

(2) Dalam melaksanakan kekuasaan sebagaimana dimaksud pada ayat (1), Kepala Desa menguasakan sebagian kekuasaannya kepada perangkat Desa.

(3) Ketentuan lebih lanjut mengenai Keuangan Desa diatur dalam Peraturan Pemerintah.

Pasal 76

(1) Aset Desa dapat berupa tanah kas desa, tanah ulayat, pasar desa, pasar hewan, tambatan perahu, bangunan desa, 
pelelangan ikan, pelelangan hasil pertanian, hutan milik desa, mata air milik desa, pemandian umum, dan aset lainnya milik desa.

(2) Aset lainnya milik desa sebagaimana dimaksud pada ayat (1) antara lain:

a. kekayaan desa yang dibeli atau diperoleh atas beban Anggaran Pendapatan dan Belanja Negara, Anggaran Pendapatan dan Belanja Daerah, serta Anggaran Pendapatan dan Belanja Desa;

b. kekayaan Desa yang diperoleh dari hibah dan sumbangan atau yang sejenis;

c. kekayaan desa yang diperoleh sebagai pelaksanaan dari perjanjian/kontrak dan lain-lain sesuai dengan ketentuan peraturan perundang-undangan;

d. hasil kerja sama desa; dan

e. kekayaan desa yang berasal dari perolehan lainnya yang sah.

(3) Kekayaan milik Pemerintah dan Pemerintah Daerah berskala lokal desa yang ada di desa dapat dihibahkan kepemilikannya kepada desa.

(4) Kekayaan milik desa yang berupa tanah disertifikatkan atas nama pemerintah desa.

(5) Kekayaan milik desa yang telah diambil alih oleh pemerintah Daerah Kabupaten/Kota dikembalikan kepada desa, kecuali yang sudah digunakan untuk fasilitas umum.

(6) Bangunan milik desa harus dilengkapi dengan bukti status kepemilikan dan ditatausahakan secara tertib.

Pasal 77

(1) Pengelolaan kekayaan milik desa dilaksanakan berdasarkan asas kepentingan umum, fungsional, kepastian hukum, 
keterbukaan, efisiensi, efektivitas, akuntabilitas, dan kepastian nilai ekonomi.

(2) Pengelolaan kekayaan milik desa dilakukan untuk meningkatkan kesejahteraan dan taraf hidup masyarakat desa serta meningkatkan pendapatan desa.

(3) Pengelolaan kekayaan milik desa sebagaimana dimaksud pada ayat (2) dibahas oleh Kepala Desa bersama Badan Permusyawaratan Desa berdasarkan tata cara pengelolaan kekayaan milik desa yang diatur dalam Peraturan Pemerintah.

Undang-Undang Republik Indonesia Nomor 23 Tahun 2014 Tentang Pemerintahan Daerah

Dalam melaksanakan urusan pemerintahan yang menjadi kewenangan daerah, Kepala Daerah dan DPRD selaku penyelenggara Pemerintahan Daerah membuat Peraturan daerah sebagai dasar hukum bagi daerah dalam menyelanggarakan otonomi daerah sesuai dengan kondisi dan aspirasi masyarakat serta kekhasan dari daerah tersebut. Peraturan daerah yang dibuat oleh daerah hanya berlaku dalam batas-batas yurisdiksi daerah yang bersangkutan.

Walaupun demikian Peraturan daerah yang ditetapkan oleh daerah tidak boleh bertentangan dengan ketentuan peraturan Perundang-undangan yang lebih tinggi tingkatannya sesuai dengan hierarki peraturan Perundang-undangan. Disamping itu Peraturan daerah sebagai bagian dari sistem peraturan perundang-undangan tidak boleh bertentangan dengan kepentingan umum sebagaimana diatur dalam kaidah penyusunan Peraturan daerah.

Daerah melaksanakan otonomi daerah yang berasal dari kewenangan Presiden yang memegang kekuasaan pemerintahan. Mengingat tanggung jawab akhir penyelenggaraan pemerintahan ada di tangan Presiden, maka konsekuensi logisnya kewenangan untuk membatalkan Peraturan daerah ada di tangan Presiden. Adalah tidak efisien apabila Presiden yang langsung membatalkan 
Peraturan daerah. Presiden melimpahkan kewenangan pembatalan Peraturan daerah Propinsi kepada Menteri sebagai pembantu Presiden yang bertanggung jawab atas Otonomi Daerah. Sedangkan untuk membatalkan Peraturan daerah Kabupaten/Kota, Presiden melimpahkan kewenangannya kepada Gubernur selaku Wakil Pemerintah Pusat di Daerah.

Untuk menghindari terjadinya kesewenang-wenangan dalam pembatalan Peraturan daerah, maka Pemerintah Daerah Provinsi dapat mengajukan keberatan pembatalan peraturan daerah provinsi yang dilakukan oleh menteri kepada Presiden. Sedangkan Pemerintah Daerah Kabupaten/Kota dapat mengajukan keberatan pembatalan peraturan daerah Kabupaten/Kota yang dilakukan gubernur sebagai wakil pemerintah pusat kepada Menteri. Dari sisi penyelenggaraan pemerintahan daerah, keputusan yang diambil oleh Presiden dan Menteri bersifat final.

Dalam rangka menciptakan tertib adminstrasi pelaporan Peraturan daerah, setiap Peraturan daerah yang akan diundangkan harus mendapatkan nomor registrasi terlebih dahulu. Peraturan Daerah Provinsi harus mendapatkan nomor register dari kementerian, sedangkan Peraturan daerah Kabupaten/Kota mendapatkan nomor register dari gubernur sebagai wakil Pemerintah Pusat. Dengan adanya pemberian nomor register tersebut akan terhimpun informasi mengenai keseluruhan peraturan daerah yang dibentuk oleh Daerah dan sekaligus juga informasi peraturan daerah secara nasional.

Peraturan Pemerintah Republik Indonesia Nomor 43 Tahun 2014 Tentang Peraturan Pelaksanaan Undang-Undang Nomor 6 Tahun 2014 Tentang Desa

Pasal 90

(1) Penyelenggaraan kewenangan desa berdasarkan hak asal usul dan kewenangan lokal berskala desa didanai oleh APB Desa. 
(2) Penyelenggaraan kewenangan lokal berskala desa sebagaimana dimaksud pada ayat (1) selain didanai oleh APB Desa, juga dapat didanai oleh anggaran pendapatan dan belanja negara dan anggaran pendapatan dan belanja daerah.

(3) Penyelenggaraan kewenangan desa yang ditugaskan oleh pemerintah didanai oleh anggaran pendapatan dan belanja negara.

(4) Dana anggaran pendapatan dan belanja negara sebagaimana dimaksud pada ayat (3) dialokasikan pada bagian anggaran kementerian/lembaga dan disalurkan melalui satuan kerja perangkat daerah kabupaten/kota.

(5) Penyelenggaraan kewenangan desa yang ditugaskan oleh pemerintah daerah didanai oleh anggaran pendapatan dan belanja daerah.

\section{Pasal 91}

Seluruh pendapatan desa diterima dan disalurkan melalui rekening kas desa dan penggunaannya ditetapkan dalam APB Desa.

\section{Pasal 92}

Pencairan dana dalam rekening kas desa ditandatangani oleh kepala desa dan bendahara desa.

\section{Pasal 93}

(1) Pengelolaan keuangan desa meliputi:
a. perencanaan;
b. pelaksanaan;
c. penatausahaan;
d. pelaporan; dan
e. pertanggungjawaban.

(2) Kepala Desa adalah pemegang kekuasaan pengelolaan keuangan desa sebagaimana dimaksud pada ayat (1). 
(3) Dalam melaksanakan kekuasaan pengelolaan keuangan desa sebagaimana dimaksud pada ayat (2), kepala desa menguasakan sebagian kekuasaannya kepada perangkat desa.

Pasal 94

Pengelolaan keuangan desa dilaksanakan dalam masa 1 (satu) tahun anggaran terhitung mulai tanggal 1 Januari sampai dengan 31 Desember.

Pasal 100

Belanja desa yang ditetapkan dalam APB Desa digunakan dengan ketentuan:

a. paling sedikit 70\% (tujuh puluh perseratus) dari jumlah anggaran belanja desa digunakan untuk mendanai penyelenggaraan pemerintahan desa, pelaksanaan pembangunan desa, pembinaan kemasyarakatan desa, dan pemberdayaan masyarakat desa; dan

b. paling banyak 30\% (tiga puluh perseratus) dari jumlah anggaran belanja desa digunakan untuk:

1. penghasilan tetap dan tunjangan kepala desa dan perangkat desa;

2. operasional pemerintah desa;

3. tunjangan dan operasional badan permusyawaratan desa; dan

4. insentif rukun tetangga dan rukun warga.

Pasal 103

(1) Kepala Desa menyampaikan laporan realisasi pelaksanaan APB Desa kepada bupati/walikota setiap semester tahun berjalan.

(2) Laporan sebagaimana dimaksud pada ayat (1) untuk semester pertama disampaikan paling lambat pada akhir bulan Juli tahun berjalan. 
(3) Laporan sebagaimana dimaksud pada ayat (1) untuk semester kedua disampaikan paling lambat pada akhir bulan Januari tahun berikutnya.

Pasal 104

(1) Selain penyampaian laporan realisasi pelaksanaan APB Desa sebagaimana dimaksud dalam Pasal 103 ayat (1), kepala desa juga menyampaikan laporan pertanggungjawaban realisasi pelaksanaan APB Desa kepada bupati/walikota setiap akhir tahun anggaran.

(2) Laporan sebagaimana dimaksud pada ayat (1) merupakan bagian yang tidak terpisahkan dari laporan penyelenggaraan Pemerintahan Desa kepada bupati/walikota melalui camat atau sebutan lain setiap akhir tahun anggaran sebagaimana dimaksud dalam Pasal 48 huruf a.

Pasal 105

Pengadaan barang dan/atau jasa di desa diatur dengan peraturan bupati/walikota dengan berpedoman pada ketentuan peraturan perundang-undangan.

Peraturan Pemerintah Republik Indonesia Nomor 60 Tahun 2014 Tentang Dana Desa Yang Bersumber Dari Anggaran Pendapatan Dan Belanja Negara

Pasal 19

(1) Dana Desa digunakan untuk membiayai penyelenggaraan pemerintahan, pembangunan, pemberdayaan masyarakat, dan kemasyarakatan.

(2) Dana Desa sebagaimana dimaksud pada ayat (1) diprioritaskan untuk membiayai pembangunan dan pemberdayaan masyarakat.

Pasal 20

Penggunaan Dana Desa mengacu pada Rencana Pembangunan Jangka Menengah Desa dan Rencana Kerja Pemerintah Desa. 
Pasal 24

(1) Kepala Desa menyampaikan laporan realisasi penggunaan Dana Desa kepada bupati/walikota setiap semester.

(2) Penyampaian laporan realisasi penggunaan Dana Desa sebagaimana dimaksud pada ayat (1) dilakukan dengan ketentuan:

a. semester I paling lambat minggu keempat bulan Juli tahun anggaran berjalan; dan

b. semester II paling lambat minggu keempat bulan Januari tahun anggaran berikutnya.

(3) Bupati/walikota menyampaikan laporan realisasi penyaluran dan konsolidasi penggunaan Dana Desa kepada Menteri dengan tembusan menteri yang menangani Desa, menteri teknis/pimpinan lembaga pemerintah non kementerian terkait, dan gubernur paling lambat minggu keempat bulan Maret tahun anggaran berikutnya.

(4) Penyampaian laporan konsolidasi sebagaimana dimaksud pada ayat (3) dilakukan setiap tahun.

\section{Pasal 25}

(1) Dalam hal kepala desa tidak atau terlambat menyampaikan laporan sebagaimana dimaksud dalam Pasal 24 ayat (2), bupati/walikota dapat menunda penyaluran Dana Desa sampai dengan disampaikannya laporan realisasi penggunaan Dana Desa.

(2) Dalam hal bupati/walikota tidak atau terlambat menyampaikan laporan sebagaimana dimaksud dalam Pasal 24 ayat (3), Menteri dapat menunda penyaluran Dana Desa sampai dengan disampaikannya laporan konsolidasi realisasi penyaluran dan penggunaan Dana Desa tahun anggaran sebelumnya. 
Peraturan Pemerintah Republik Indonesia Nomor 22 Tahun 2015 Tentang Perubahan Atas Peraturan Pemerintah Nomor 60 Tahun 2014 Tentang Dana Desa Yang Bersumber Dari Anggaran Pendapatan Dan Belanja Negara

Pasal 8

Penyusunan pagu anggaran Dana Desa sebagaimana dimaksud dalam Pasal 3 dilaksanakan sesuai dengan ketentuan peraturan perundang-undangan di bidang penyusunan rencana dana pengeluaran Bendahara Umum Negara.

Pasal27

(1) Dalam hal terdapat SiLPA Dana Desa lebih dari 30\% (tiga puluh per seratus) pada akhir tahun anggararn sebelumnya, bupati/walikota memberikan sanksi administratif kepada desa yang bersangkutan.

(2) Sanksi sebagaimana dimaksud pada ayat (1) berupa penundaan penyaluran Dana Desa tahap I tahun anggaran berjalan sebesar SiLPA Dana Desa.

(3) Dalam hal pada tahun anggaran berjalan masih terdapat SiLPA Dana Desa lebih dari 30\% (tiga puluh per seratus), bupati/walikota memberikan sanksi administratif kepada Desa yang bersangkutan.

(4) Sanksi sebagaimana dimaksud pada ayat (3) berupa pemotongan Dana Desa tahun anggaran berikutnya sebesar SiLPA Dana Desa tahun berjalan.

(5) Pemotongan penyaluran Dana Desa sebagaimana dimaksud pada ayat (4) menjadi dasar Menteri melakukan pemotongan penyaluran Dana Desa untuk kabupaten I kota tahun anggaran berikutnya

(6) Ketentuan mengenai pengenaan sanksi administratif sebagaimana dimaksud pada ayat (1) dan ayat (3) diatur dengan peraturan bupati/walikota. 
Peraturan Pemerintah Republik Indonesia Nomor 47 Tahun 2015 Tentang Perubahan Atas Peraturan Pemerintah Nomor 43 Tahun 2014 Tentang Peraturan Pelaksanaan Undang-Undang Nomor 6 Tahun 2014 Tentang Desa

\section{Pasal 100}

(1) Belanja Desa yang ditetapkan dalam APB Desa digunakan dengan ketentuan:

a. paling sedikit 70\% (tujuh puluh per seratus) dari jumlah anggaran belanja Desa digunakan untuk mendanai penyelenggaraan Pemerintahan Desa, pelaksanaan pembangunan desa, pembinaan kemasyarakatan desa, dan pemberdayaan masyarakat desa; dan

b. paling banyak 30\% (tiga puluh per seratus) dari jumlah anggaran belanja desa digunakan untuk:

1. penghasilan tetap dan tunjangan kepala desa dan perangkat desa;

2. operasional pemerintahan desa;

3. tunjangan dan operasional Badan Permusyawaratan Desa; dan

4. insentif rukun tetangga dan rukun warga.

(2) Perhitungan belanja desa sebagaimana dimaksud pada ayat (1) di luar pendapatan yang bersumber dari hasil pengelolaan tanah bengkok atau sebutan lain.

(3) Hasil pengelolaan tanah bengkok atau sebutan lain sebagaimana dimaksud pada ayat (2) dapat digunakan untuk tambahan tunjangan kepala desa dan perangkat desa selain penghasilan tetap dan tunjangan kepala desa sebagaimana dimaksud pada ayat (1) huruf b angka 1.

(4) Ketentuan lebih lanjut mengenai hasil pengelolaan tanah bengkok atau sebutan lain sebagaimana dimaksud pada ayat (2) diatur dengan peraturan bupati/walikota. 
Pasal 104

(1) Selain penyampaian laporan realisasi pelaksanaan APB Desa sebagaimana dimaksud dalam Pasal 103 ayat (1), kepala desa juga menyampaikan laporan pertanggungjawaban realisasi pelaksanaan APB Desa kepada bupati/walikota setiap akhir tahun anggaran yang telah ditetapkan dengan peraturan desa.

(2) Laporan sebagaimana dimaksud pada ayat (1) merupakan bagian yang tidak terpisahkan dari laporan penyelenggaraan Pemerintahan Desa kepada bupati/walikota melalui camat atau sebutan lain setiap akhir tahun anggaran sebagaimana dimaksud dalam Pasal 48 huruf a.

Pasal 106

Ketentuan lebih lanjut mengenai pengelolaan keuangan desa diatur dalam peraturan menteri yang menyelenggarakan urusan pemerintahan di bidang pemerintahan dalam negeri.

Pasal 110

(1) Pengelolaan kekayaan milik desa bertujuan meningkatkan kesejahteraan masyarakat desa dan meningkatkan pendapatan desa.

(2) Pengelolaan kekayaan milik desa diatur dengan peraturan desa dengan berpedoman pada peraturan menteri yang menyelenggarakan urusan pemerintahan di bidang pemerintahan dalam negeri.

\section{Pasal 113}

Ketentuan lebih lanjut mengenai pengelolaan kekayaan milik desa diatur dengan peraturan menteri yang menyelenggarakan urusan pemerintahan di bidang pemerintahan dalam negeri

Peraturan Menteri Dalam Negeri Republik Indonesia Nomor 113 Tahun 2014 Tentang Pengelolaan Keuangan Desa 
Pasal 3

Kepala Desa adalah pemegang kekuasaan pengelolaan keuangan desa dan mewakili Pemerintah Desa dalam kepemilikan kekayaan milik desa yang dipisahkan.

Pasal 5

(1) Sekretaris Desa sebagaimana dimaksud dalam Pasal 4 ayat (1) huruf a bertindak selaku koordinator pelaksana teknis pengelolaan keuangan desa.

Pasal 7

(1) Bendahara sebagaimana dimaksud dalam Pasal 4 ayat (1) huruf C di jabat oleh staf pada urusan keuangan.

(2) Bendahara sebagaimana dimaksud pada ayat (1) mempunyai tugas: menerima, menyimpan, menyetorkan/membayar, menatausahakan, dan mempertanggungjawabkan penerimaan pendapatan desa dan pengeluaran pendapatan desa dalam rangka pelaksanaan APBDesa.

Pasal 8

(1) APB Desa,terdiri atas:
a. Pendapatan Desa;
b. Belanja Desa; dan
C. Pembiayaan Desa.

Pasal 9

(1) Pendapatan Desa sebagaimana dimaksud dalam Pasal 8 ayat (1)huruf a, meliputi semua penerimaan uang melalui rekening desa yang merupakan hak desa dalam 1 (satu) tahun anggaran yang tidak perlu dibayar kembali oleh desa.

(2) Pendapatan Desa sebagaimana dimaksud dalam Pasal 8 ayat (1), terdiri atas kelompok:

a. Pendapatan Asli Desa (PADesa);

b. Transfer; dan 

c. Pendapatan Lain-Lain.

(3) Kelompok PADesa sebagaimana dimaksud pada ayat (2) huruf a, terdiri atas jenis:

a. Hasil usaha;

b. Hasil aset;

C. Swadaya, partisipasi dan Gotong royong; dan

d. Lain-lain pendapatan asli desa.

(4) Hasil usaha desa sebagaimana dimaksud pada ayat (3) huruf a antara lain hasil Bumdes, tanah kas desa.

(5) Hasil aset sebagaimana dimaksud pada ayat (3) huruf b antara lain tambatan perahu, pasar desa, tempat pemandian umum, jaringan irigasi.

(6) Swadaya, partisipasi dan gotong royong sebagaimana dimaksud pada ayat (3) huruf c adalah membangun dengan kekuatan sendiri yang melibatkan peran serta masyarakat berupa tenaga, barang yang dinilai dengan uang.

Pasal 10

(1) Kelompok transfer sebagaimana dimaksud dalam Pasal 9 ayat (2) huruf b, terdiri atas jenis:

a. Dana Desa;

b. Bagian dari Hasil Pajak Daerah Kabupaten/Kota dan Retribusi Daerah;

c. Alokasi Dana Desa (ADD);

d. Bantuan Keuangan dari APBD Provinsi; dan

e. Bantuan Keuangan APBD Kabupaten/Kota.

(2) Bantuan Keuangan dari APBD Provinsi dan Kabupaten/Kota sebagaimana dimaksud pada ayat (1) huruf d dan e dapat bersifat umum dan khusus.

(3) Bantuan Keuangan bersifat khusus sebagaimana dimaksud pada ayat (2) dikelola dalam APBDesa tetapi tidak diterapkan dalam 
ketentuan penggunaan paling sedikit 70\% (tujuh puluh perseratus) dan paling banyak 30\% (tiga puluh perseratus).

(4) Kelompok pendapatan lain-lain sebagaimana dimaksud pada ayat (2) huruf $c$, terdiri atas jenis:

a. Hibah dan Sumbangan dari pihak ketiga yang tidak mengikat; dan

b. Lain-lain pendapatan Desa yang sah.

Pasal 11

(1) Hibah dan sumbangan dari pihak ketiga yang tidak mengikat sebagaimana dimaksud dalam Pasal 10 ayat (2) huruf a adalah pemberian berupa uang dari pihak ke tiga.

(2) Lain-lain pendapatan Desa yang sah sebagaimana dimaksud dalam Pasal 10 ayat (2) huruf b, antara lain pendapatan sebagai hasil kerjasama dengan pihak ketiga dan bantuan perusahaan yang berlokasi di desa.

Pasal 12

(1) Belanja desa sebagaimana dimaksud dalam Pasal 8 ayat (1) huruf $b$, meliputi semua pengeluaran dari rekening desa yang merupakan kewajiban desa dalam 1 (satu) tahun anggaran yang tidak akan diperoleh pembayarannya kembali oleh desa.

(2) Belanja desa sebagaimana dimaksud pada ayat (1) dipergunakan dalam rangka mendanai penyelenggaraan kewenangan desa.

\section{Pasal 13}

(1) Klasifikasi belanja desa sebagaimana dimaksud dalam pasal 8 ayat (1) huruf b, terdiri atas kelompok:

a. Penyelenggaraan Pemerintahan Desa;

b. Pelaksanaan Pembangunan Desa;

c. Pembinaan Kemasyarakatan Desa;

d. Pemberdayaan Masyarakat Desa; dan

e. Belanja Tak Terduga. 
Pasal 14

(1) Jenis belanja pegawai sebagaimana dimaksud dalam Pasal 13 ayat (3) huruf a, dianggarkan untuk pengeluaran penghasilan tetap dan tunjangan bagi Kepala Desa dan Perangkat Desa serta tunjangan BPD.

Pasal 15

(1) Belanja Barang dan Jasa sebagaimana dimaksud dalam Pasal 13 ayat (3) huruf b digunakan untuk pengeluaran pembelian/pengadaan barang yang nilai manfaatnya kurang dari 12 (dua belas) bulan.

(2) Belanja barang/jasa sebagaimana dimaksud pada ayat (1) antara lain:
a. alat tulis kantor;
b. benda pos;
C. bahan/material;
d. pemeliharaan;
e. cetak/penggandaan;
f. sewa kantor desa;
g. sewa perlengkapan dan peralatan kantor;
h. makanan dan minuman rapat;
i. pakaian dinas dan atributnya;
j. perjalanan dinas;
k. upah kerja;
l. honorarium narasumber/ahli;
m. operasional Pemerintah Desa;
n. operasional BPD;
o. insentif Rukun Tetangga /Rukun Warga; dan
p. pemberian barang pada masyarakat/kelompok masyarakat.


Pasal 17

(1) Dalam keadaan darurat dan/atau Keadaan Luar Biasa (KLB), pemerintah Desa dapat melakukan belanja yang belum tersedia anggarannya.

(2) Keadaan darurat dan/atau KLB sebagaimana dimaksud pada ayat (1) merupakan keadaan yang sifatnya tidak biasa atau tidak diharapkan berulang dan/atau mendesak.

(3) Keadaan darurat sebagaimana dimaksud ayat (1) yaitu antara lain dikarenakan bencana alam, sosial, kerusakan sarana dan prasarana.

(4) Keadaan luar biasa sebagaimana dimaksud ayat (1) karena $\mathrm{KLB} /$ wabah.

(5) Keadaan darurat dan luar biasa sebagaimana ayat (3) ditetapkan dengan Keputusan Bupati/walikota.

(6) Kegiatan dalam keadaan darurat sebagaimana dimaksud pada ayat (2) dianggarkan dalam belanja tidak terduga.

Peraturan Menteri Desa, Pembangunan Daerah Tertinggal, Dan Transmigrasi Republik Indonesia Nomor 22 Tahun 2016 Tentang Penetapan Prioritas Penggunaan Dana Desa Tahun 2017

Pasal 3

Prioritas penggunaan Dana Desa didasarkan pada prinsip-prinsip:

a. Keadilan, dengan mengutamakan hak dan kepentingan seluruh warga desa tanpa membeda-bedakan;

b. Kebutuhan prioritas, dengan mendahulukan kepentingan desa yang lebih mendesak, lebih dibutuhkan dan berhubungan langsung dengan kepentingan sebagian besar masyarakat desa;

c. Kewenangan Desa, dengan mengutamakan kewenangan hak asal usul dan kewenangan lokal berskala desa;

d. Partisipatif, dengan mengutamakan prakarsa dan kreatifitas masyarakat; 
e. Swakelola dan berbasis sumber daya desa mengutamakan pelaksanaan secara mandiri dengan pendayagunaan sumberdaya alam desa, mengutamakan tenaga, pikiran dan keterampilan warga desa dan kearifan lokal; dan

f. Tipologi Desa, dengan mempertimbangkan keadaan dan kenyataan karakteristik geografis, sosiologis, antropologis, ekonomi, dan ekologi desa yang khas, serta perubahan atau perkembangan dan kemajuan desa.

Pasal 4

(1) Prioritas Penggunaan Dana Desa untuk membiayai pelaksanaan program dan kegiatan di bidang Pembangunan Desa dan Pemberdayaan Masyarakat Desa.

(2) Prioritas penggunaaan dana desa sebagaimana dimaksud pada ayat (1), dipublikasikan kepada masyarakat oleh Pemerintah Desa di ruang publik atau ruang yang dapat diakses masyarakat desa. 


\section{BAB IV \\ LANDASAN FILOSOFIS, YURIDIS, DAN SOSIOLOGIS}

\section{A. Landasan Filosofis}

Penjelasan Pasal 18 amandemen ke-4 Undang-Undang Dasar Negara Republik Indonesia Tahun 1945 memuat beberapa hal pokok tentang daerah otonom/pemerintahan daerah sebagai berikut:

1. Daerah besar dan kecil bukanlah negara bagian karena daerah tersebut dibentuk dalam kerangka negara kesatuan

2. Daerah besar dan kecil ada yang bersifat otonom dan ada yang bersifat administrasi

3. Daerah yang mempunyai hak-hak asal-usul yang bersifat istimewa adalah swapraja dan desa yang semacam dengan itu

4. Republik Indonesia akan menghormati kedudukan daerah yang mempunyai hak asal-usul yang bersifat istimewa itu ${ }^{16}$.

Berkaitan dengan uraian diatas, Philipus M. Hadjon mengemukakan pendapat, bahwa prinsip-prinsip penyelenggaraan pemerintah daerah pasca amandemen khususnya prinsip yang terkandung dalam pasal 18 adalah:

1. Prinsip pembagian daerah yang bersifat hirarkis (ayat 1)

2. Prinsip otonomi dan tugas pembantuan (ayat 2)

3. Prinsip demokrasi (ayat 3 dan 4)

4. Prinsip otonomi seluas-luasnya (ayat 5$)^{17}$.

Kaidah Pasal 18 Undang-Undang Dasar 1945 yang menjiwai pelaksanaan pemerintahan di daerah dalam bingkai negara kesatuan, sinkron dengan Pasal 1 ayat (1) Undang-Undang Dasar Tahun 1945 yang secara tegas menghendaki Republik Indonesia sebagai negara kesatuan, bukan negara serikat atau federal. Penegasan ini memberikan indikasi bahwa di dalam wilayah Negara

16 Dr. Agussalim Andi Gadjong, SH, Pemerintahan Daerah, Ghalia Indonesia, Bogor, 2007, hal 224

7 H.M. Arief Muljadi, SH, Prinsip-Prinsip Negara Kesatuan dan Desentralisasi, Prestasi Pustaka Publiser,Jakarta, 2010, hal. 37

52 Naskah Akademik Rancangan Undang-undang Peraturan Daerah Keuangan Desa 
Republik Indonesia tidak ada daerah yang bersifat negara (staat), yang menjalankan pemerintahan di daerah tetap dalam satu kebulatan bingkai pemerintahan negara kesatuan. Pada tanggal 15 Januari 2014, Pemerintah telah menetapkan Undang-Undang Nomor 6 Tahun 2014 Tentang Desa. Landasan filosofis lahirnya Undangundang tersebut didasarkan kepada pertimbangan bahwa desa memiliki hak asal usul dan hak tradisional dalam mengatur kepentingan masyarakat setempat dan berperan mewujudkan citacita kemerdekaan berdasarkan Undang-Undang Dasar 1945. Secara yuridis, Undang-Undang Nomor 6 Tahun 2014 lahir berdasarkan amanah Pasal 18B ayat (2) Undang-Undang Dasar 1945, yang menyebutkan: "Negara mengakui dan menghormati kesatuankesatuan masyarakat hukum adat beserta hak-hak tradisionalnya sepanjang masih hidup dan sesuai dengan perkembangan masyarakat dan prinsip Negara Kesatuan Republik Indonesia, yang diatur dalam undang-undang"18.

Desa atau yang disebut dengan nama lain telah ada sebelum Indonesia terbentuk. Penjelasan Pasal 18 Undang-Undang Dasar 1945 (sebelum amandemen) menyebutkan bahwa "Dalam teritori Negara Indonesia terdapat lebih kurang 250 "Zelfbesturende landschappen" dan "Volksgemeenschappen" seperti desa di Jawa dan Bali, Nagari di Minangkabau, dusun dan marga di Palembang, dan sebagainya. Daerah-daerah itu mempunyai susunan asli dan oleh karenanya dapat dianggap sebagai daerah yang bersifat istimewa. Negara Republik Indonesia menghormati kedudukan daerah-daerah istimewa tersebut dan segala peraturan negara yang mengenai daerah-daerah itu akan mengingati hak-hak asal usul daerah tersebut”. Oleh sebab itu, lahirnya Undang-undang Nomor 6 Tahun 2014 merupakan bentuk pengakuan dan jaminan

18 Youla C. Sajangbati, 2015, Penyelenggaraan Pemerintahan Desa Berdasarkan Undang-Undang Nomor 6 Tahun 2014. Lex Administratum, Vol. Iii/No.2/April

53 Naskah Akademik Rancangan Undang-undang Peraturan Daerah Keuangan Desa 


\section{।}

keberlangsungan desa oleh negara dalam wilayah Negara Kesatuan Republik Indonesia.

Salah satu subtansi yang diatur dalam Undang-undang Nomor 6 Tahun 2014 adalah mengenai keuangan desa. Pasal 1 angka 10 Undang-undang Nomor 6 Tahun 2014 memberikan definisi keuangan desa adalah semua hak dan kewajiban yang dapat dinilai dengan uang serta segala sesuatu berupa uang dan barang yang berhubungan dengan pelaksanaan hak dan kewajiban desa. Pengertian hak dan kewajiban tersebut adalah semua yang menimbulkan pendapatan, belanja, pembiayaan dan pengelolaan Keuangan Desa. Undang-undang Nomor 6 Tahun 2014 menegaskan desa mempunyai sumber pendapatan desa yang terdiri atas: 1) Pendapatan asli Desa; 2) Bagi hasil pajak daerah dan retribusi daerah Kabupaten/Kota; 3) Bagian dari dana perimbangan keuangan pusat dan daerah yang diterima Kabupaten/Kota; 4) Alokasi anggaran dari APBN; 5) Bantuan keuangan dari APBD Provinsi dan APBD Kabupeten/Kota; serta 6) Hibah dan sumbangan yang tidak mengikat dari pihak ketiga.

Kewenangan pengelolaan keuangan desa dilaksanakan oleh Kepala Desa sebagaimana disebutkan dalam Pasal 26 ayat (2) huruf c, yang menyebutkan "Kepala Desa berwenang memegang kekuasaan pengelolaan keuangan dan Aset Desa". Adanya Undangundang Nomor 6 Tahun 2014 yang memberikan kewenangan dibidang pengelolaan keuangan bagi desa disatu sisi layak disyukuri sebagai sarana untuk mewujudkan kesejahteraan bagi masyarakat di desa, akan tetapi disisi lain akan berdampak kepada implikasi yuridis terkait pengelolaan keuangan desa itu sendiri. Hal ini berdasarkan pertimbangan bahwa profil desa di seluruh Indonesia yang beragam bentuknya, apalagi pengertian desa dalam Undangundang Nomor 6 Tahun 2014 menyamakan antara desa (definitif) dan desa adat, yang tentu saja kemampuan aparatur pemerintahan 
desa tersebut berbeda tingkatannya dalam pengelolaan keuangan desa. Konsekwensi bagi aparatur Pemerintahan Desa termasuk Kepala Desa dan perangkat desa lainnya adalah diwajibkan untuk melaksanakan pengelolaan keuangan desa secara rigid mengikuti Peraturan Perundang-undangan yang mengatur pengelolaan keuangan. Apabila pemerintahan desa tidak mengikuti peraturan Perundang-undangan tersebut, maka akan menimbulkan sejumlah implikasi yuridis bagi mereka ${ }^{19}$.

Reformasi penyelenggaraan pemerintahan desa pada hakekatnya adalah suatu proses pembalikan paradigma politik, dimana proses demokratisasi yang selama Orde Baru berproses dari atas, kemudian dibalik melalui proses yang berangkat dari desa. Dalam paradigma baru tersebut, desa merupakan kesatuan hukum yang otonom dan memiliki hak dan wewenang untuk mengatur rumah tangga sendiri ${ }^{20}$. Berdasarkan Undang-undang Nomor 6 Tahun 2014 Tentang Pemerintahan Daerah, Desa tidak lagi merupakan level administrasi, tidak lagi menjadi bawahan daerah, melainkan menjadi independent community, yang masyarakatnya berhak berbicara atas kepentingan sendiri dan bukan ditentukan dari atas ke bawah. Desa yang selama ini diperankan sebagai figuran dan objek, sekarang beperan sebagai aktor ${ }^{21}$.

\section{B. Landasan Yuridis}

Keuangan desa dijelaskan dalam Undang-undang Nomor 6 Tahun 2014 Tentang Desa Pasal 71 ayat 1 yakni semua hak dan kewajiban desa yang dapat dinilai dengan uang serta segala sesuatu berupa uang dan barang yang berhubungan dengan pelaksanaan hak dan kewajiban desa. Selanjutnya Pasal 71 Ayat (2) menyebutkan

19 Youla C. Sajangbati, 2015, Penyelenggaraan Pemerintahan Desa Berdasarkan Undang-Undang Nomor 6 Tahun 2014. Lex Administratum, Vol. Iii/No.2/April

20 Busrizalti, H.M, 2013, Hukum Pemda Otonomi Daerah Dan Implikasinya, Total Media, Yogyakarta.

21 Sunanro Siswanto. 2008. Hukum Pemerintahan Daerah Di Indonesia. Sinar Grafika. Jakarta. Hal 8

55 Naskah Akademik Rancangan Undang-undang Peraturan Daerah Keuangan Desa 
bahwa hak dan kewajiban menimbulkan pendapatan, belanja, pembiayaan, dan pengelolaan Keuangan Desa ${ }^{22}$.

Peraturan Pemerintah Nomor 47 Tahun 2015 Tentang perubahan atas Peraturan Pemerintah Nomor 43 tahun 2014 Tentang peraturan pelaksanaan Undang-undang Nomor 6 Tahun 2014 Tentang Desa pasal 1 ayat 8 dan 9 menjelaskan: Pasal 1 ayat 8 Dana Desa adalah dana yang bersumber dari anggaran pendapatan dan belanja negara yang diperuntukkan bagi desa yang ditransfer melalui anggaran pendapatan dan belanja daerah kabupaten/kota dan digunakan untuk membiayai penyelenggaraan pemerintahan, pelaksanaan pembangunan, pembinaan kemasyarakatan, dan pemberdayaan masyarakat.

Permendagri Nomor 113 Tahun 2014 Tentang Pengelolaan Keuangan Desa Pasal 1 ayat 5. Keuangan Desa adalah semua hak dan kewajiban desa yang dapat dinilai dengan uang serta segala sesuatu berupa uang dan barang yang berhubungan dengan pelaksanaan hak dan kewajiban desa.

Prinsip pengeloaan keuangan di desa dalam rangka Good Governance harus mencakup beberapa aspek diantaranya adalah:

1. Aspiratif, dalam pengambilan kebijakan tentang pengelolaan keuangan Desa pemerintah desa dan BPD harus mendengar aspirasi dari masyarakat.

2. Partisipatif, dalam pengambilan kebijakan pengelolaan keuangan Desa, pemerintah desa harus melibatkan masyarakat.

3. Transparan, masyarakat memperoleh informasi yang cukup tentang APBDes, termasuk program pembangunan,lelang kas Desa, bantuan pemerintah dan pungutan ke masyarakat.

4. Akuntabilitas, dalam mengelola keungan desa harus berdasarkan kepada aturan yang berlaku² ${ }^{23}$

22 Sahrul Haidin. 2017. Pelaksanaan Pengelolaan Keuangan Desa Setelah Berlakunya UndangUndang Nomor 6 Tahun 2014 Tentang Desa. Ilmu Hukum Universitas Mataram 
Kebijakan yang berupa undang-undang maupun aturan lain tentu memiliki dasar untuk dijadikan sebagai acuan dalam pembuatannya termasuk Pengakuan Pemerintah Republik Indonesia terhadap desa. Pemerintah desa tidak disebutkan secara jelas dalam Undang-Undang Dasar 1945. Namun ditafsirkan dalam Pasal 18B Undang-Undang Dasar Negara Republik Indonesia Tahun 1945 sebagai berikut : 1 . Negara mengakui dan menghormati satuansatuan pemerintahan daerah yang bersifat khusus atau bersifat istimewa yang diatur dengan undang-undang. 2. Negara mengakui dan menghormati kesatuan-kesatuan masyarakat hukum adat beserta hak-hak tradisionalnya sepanjang masih hidup dan sesuai dengan perkembangan masyarakat dan prinsip Negara Kesatuan Republik Indonesia, yang diatur dalam undang-undang.

Bertitik tolak pada pengertian sebagaimana ketentuan diatas, terlihat bahwa desa (atau dengan nama lain) sebagai sebuah pemerintahan yang otonom dan diakui keberadaannya oleh Negara yakni Pemerintah Indonesia. Sebagaimana suatu pemerintahan, desa mempunyai tugas dan fungsi untuk menyelenggarakan emerintahan desa, melaksanakan pembangunan desa, pembinaan kemasyarakatan desa, dan pemberdayaan masyarakat desa. keuangan desa, dalam Undang-undang Nomor 6 Tahun 2014 Tentang Desa Pasal 1 angka (10) semua hak dan kewajiban desa yang dapat dinilai dengan uang serta segala sesuatu berupa uang dan barang yang berhubungan dengan pelaksanaan hak dan kewajiban desa. Pasal 71 Ayat (2) menyebutkan bahwa hak dan kewajiban menimbulkan pendapatan, belanja, pembiayaan, dan pengelolaan keuangan desa.

Peraturan Pemerintah Nomor 47 Tahun 2015 Tentang perubahan atas Peraturan Pemerintah Nomor 43 Tahun 2014 tentang peraturan pelaksanaan Undang-undang Nomor 6 Tahun 2014 Tentang Desa pasal 1 ayat 8 dan 9 menjelaskan: Pasal 1 ayat 8 Dana

23 Edy Supriadi. Pertanggungjawaban Kepala Desa Dalam Pengelolaan Keuangan Desa Berdasarkan Undang-Undang Nomor 6 Tahun 2014 Tentang Desa. Jurnal IUS (Kajian Hukum dan Keadilan), Vol III | Nomor 8

57 Naskah Akademik Rancangan Undang-undang Peraturan Daerah Keuangan Desa 
Desa adalah dana yang bersumber dari anggaran pendapatan dan belanja negara yang diperuntukkan bagi desa yang ditransfer melalui anggaran pendapatan dan belanja daerah kabupaten/kota dan digunakan untuk membiayai penyelenggaraan pemerintahan, pelaksanaan pembangunan, pembinaan kemasyarakatan, dan pemberdayaan masyarakat dan pasal 1 ayat 9 Alokasi Dana Desa, selanjutnya disingkat ADD, adalah dana perimbangan yang diterima kabupaten/ kota dalam anggaran pendapatan dan belanja daerah kabupaten/kota setelah dikurangi Dana Alokasi Khusus. Permendagri Nomor 113 Tahun 2014 Tentang Pengelolaan Keuangan Desa pasal 1 ayat 5, 6, 9 dan 10 menjelaskan: Pasal 1 ayat 5 . Keuangan Desa adalah semua hak dan kewajiban Desa yang dapat dinilai dengan uang serta segala sesuatu berupa uang dan barang yang berhubungan dengan pelaksanaan hak dan kewajiban desa. Dan pasal 1 ayat 6 Pengelolaan Keuangan Desa adalah keseluruhan kegiatan yang meliputi perencanaan, pelaksanaan, penatausahaan, pelaporan, dan pertanggungjawaban keuangan desa, pasal 1 ayat 9 Dana Desa adalah dana yang bersumber dari Anggaran Pendapatan dan Belanja Negara yang diperuntukkan bagi desa yang ditransfer melalui Anggaran Pendapatan dan Belanja Daerah Kabupaten/Kota dan digunakan untuk membiayai penyelenggaraan pemerintahan, pelaksanaan pembangunan, pembinaan kemasyarakatan, dan pemberdayaan masyarakat dan pasal 1 ayat 10 yakni Alokasi Dana Desa, selanjutnya disingkat ADD, adalah dana perimbangan yang diterima kabupaten/kota dalam Anggaran Pendapatan dan Belanja Daerah kabupaten/kota setelah dikurangi Dana Alokasi Khusus.

Peraturan Menteri Desa, Pembangunan Daerah Tertinggal, dan Transmigrasi Nomor 5 tahun 2015 tentang penetapan prioritas penggunaan dana desa tahun 2015 Pasal 2, pasal 3 dan pasal 4 yakni: Pasal 2 Dana Desa yang bersumber dari APBN digunakan untuk mendanai pelaksanaan kewenangan berdasarkan hak asal usul dan kewenangan lokal berskala desa yang diatur dan diurus oleh desa, Pasal 3 Dana Desa diprioritaskan untuk membiayai belanja 
pembangunan pemberdayaan masyarakat desa dan Pasal 4 Penggunaan Dana Desa tertuang dalam prioritas belanja Desa yang disepakati dalam Musyawarah Desa.

Pasal 2 Dana Desa yang bersumber dari APBN digunakan untuk mendanai pelaksanaan kewenangan berdasarkan hak asal usul dan kewenangan lokal berskala Desa yang diatur dan diurus oleh Desa. Pasal 3 Dana Desa diprioritaskan untuk membiayai belanja pembangunan dan pemberdayaan masyarakat Desa. Pasal 4 Penggunaan Dana Desa tertuang dalam prioritas belanja Desa yang disepakati dalam Musyawarah Desa. Pasal 5 Prioritas penggunaan Dana Desa untuk pembangunan Desa dialokasikan untuk mencapai tujuan pembangunan Desa yaitu meningkatkan kesejahteraan masyarakat Desa dan kualitas hidup manusia serta penanggulangan kemiskinan, melalui: a. pemenuhan kebutuhan dasar; b. pembangunan sarana dan prasarana Desa; c. pengembangan potensi ekonomi lokal; dan d. pemanfaatan sumber daya alam dan lingkungan secara berkelanjutan. Pasal 6 Prioritas penggunaan Dana Desa sebagaimana dimaksud dalam Pasal 5 huruf a, meliputi: a. pengembangan pos kesehatan Desa dan Polindes; b. pengelolaan dan pembinaan Posyandu; dan c. pembinaan dan pengelolaan pendidikan anak usia dini. Pasal 7 Prioritas penggunaan Dana Desa sebagaimana dimaksud dalam Pasal 5 huruf $b$ dan huruf $c$ untuk mendukung target pembangunan sektor unggulan dalam Rencana Pembangunan Jangka Menengah Nasional (RPJMN) 2015-2019 dan Rencana Kerja Pemerintah (RKP) setiap tahunnya, yang diprioritaskan untuk: a. mendukung kedaulatan pangan; b. mendukung kedaulatan energi; c. mendukung pembangunan kemaritiman dan kelautan; dan d. mendukung pariwisata dan industri. Pasal 8 Prioritas penggunaan Dana Desa sebagaimana dimaksud dalam Pasal 5 huruf b didasarkan atas kondisi dan potensi desa, sejalan dengan pencapaian target RPJM Desa dan RKP Desa setiap tahunnya, yang diantaranya dapat meliputi: a. pembangunan dan pemeliharaan jalan desa; b. pembangunan dan pemeliharaan 
jalan usaha tani; c. pembangunan dan pemeliharaan embung desa; d. pembangunan energi baru dan terbarukan; e. pembangunan dan pemeliharaan sanitasi lingkungan; f. pembangunan dan pengelolaan air bersih berskala desa; g. pembangunan dan pemeliharaan irigasi tersier; h. pembangunan dan pemeliharaan serta pengelolaan saluran untuk budidaya perikanan; dan i. pengembangan sarana dan prasarana produksi di desa.

Membahas tentang Sistem Informasi Akuntansi. Untuk sistem informasi secara umum sudah diatur oleh Undang-undang Nomor 6 Tahun 2014 Tentang Desa pada pasal 86 menjelaskan: 1. Desa berhak mendapatkan akses informasi melalui sistem informasi desa yang dikembangkan oleh Pemerintah Daerah Kabupaten/Kota. 2. Pemerintah dan Pemerintah Daerah wajib mengembangkan sistem informasi desa dan pembangunan kawasan perdesaan. 3. Sistem informasi desa sebagaimana dimaksud pada ayat (2) meliputi fasilitas perangkat keras dan perangkat lunak, jaringan, serta sumber daya manusia. 4. Sistem informasi desa sebagaimana dimaksud pada ayat (2) meliputi data desa, data pembangunan desa, kawasan perdesaan, serta informasi lain yang berkaitan dengan pembangunan desa dan pembangunan kawasan perdesaan. 5. Sistem informasi desa sebagaimana dimaksud pada ayat (2) dikelola oleh Pemerintah Desa dan dapat diakses oleh masyarakat desa dan semua pemangku kepentingan. 6. Pemerintah Daerah Kabupaten/Kota menyediakan informasi perencanaan pembangunan Kabupaten/Kota untuk Desa. Tanggung-jawab pengembangan sistem informasi desa ini diserahkan kepada Pemerintah Kabupaten/kota. Informasi yang dikelola dalam sistem tersebut adalah informasi umum yang cenderung lebih luas dan berbedabeda ragamnya antar kabupaten, sesuai dengan perbedaan fokus pembangunan di daerah masing-masing. Sedangkan pembahasan sistem informasi akuntansi adalah spesifik dan mempunyai standar yang sama pada seluruh desa di Indonesia seperti masa sebelumnya, diatur oleh Permendagri Nomor 37 Tahun 2007 Tentang Pedoman 
Pengelolaan Keuangan Desa. Karena itu pengembangan sistem informasi akuntansi yang dilakukan pada beberapa bagian, ada yang di pusat, ada yang di pemerintah daerah, dan ada yang di desa itu sendiri yang semuanya memanfaatkan jaringan komunikasi data selular dengan tujuan keseragaman sistem dan memperkecil biaya investasi perangkat keras.

\section{Landasan Sosiologis}

Ihwal keuangan desa diatur dalam Pasal 71-75 Undang-undang Desa. Dalam Pasal 71 ayat (1), dinyatakan bahwa "Keuangan Desa adalah semua hak dan kewajiban desa yang dapat dinilai dengan uang serta segala sesuatu berupa uang dan barang yang berhubungan dengan pelaksanaan hak dan kewajiban desa." Selanjutnya, pengaturan mengenai keuangan desa dan hal lain yang terkait dengannya dijabarkan lebih lanjut dalam berbagai peraturan, di antaranya Peraturan Pemerintah Nomor 43 Tahun 2014 Tentang Peraturan Pelaksanaan Undang-undang Nomor 6 Tahun 2014 Tentang Desa, Peraturan Pemerintah Nomor 60 Tahun 2014 Tentang Dana Desa yang Bersumber dari APBN, Peraturan Pemerintah Nomo 22 Tahun 2015 Tentang Perubahan atas Peraturan Pemerintah Nomor 60 Tahun 2014, Peraturan Pemerintah Nomor 47 Tahun 2015 Tentang Perubahan atas Peraturan Pemerintah Nomor 43 Tahun 2014, Permendagri Nomor 113 Tahun 2014 Tentang Pengelolaan Keuangan Desa, Peraturan Menteri Keuangan Nomor 241/PMK.07/2014 Tentang Pelaksanaan dan Pertanggungjawaban Transfer ke Daerah dan Dana Desa, Peraturan Menteri Keuangan Nomor 250/PMK.07/-2014 Tentang Pengalokasian Transfer ke Daerah dan Dana Desa, Peraturan Menteri Keuangan Nomor 93/PMK.07/2015 Tentang Tata Cara Pengalokasian, Penyaluran, Penggunaan, Pemantauan, dan Evaluasi Dana Desa, dan Peraturan 
Menteri Desa Tertinggal Nomor 5 Tahun 2015 Tentang Prioritas Penggunaan Dana Desa.

Mengenai pendapatan desa, seturut Permendagri Nomor 113 Tahun 2014 Bab IV Bagian Kesatu (Pasal 9-11), dinyatakan bahwa pendapatan desa terdiri atas tiga elemen, yakni 1) PAD (yang terdiri atas hasil usaha; hasil aset; swadaya, partisipasi, dan gotongroyong; dan lain-lain PAD); 2) transfer (terdiri atas dana desa; PDRB; ADD; bantuan keuangan APBD provinsi; dan bantuan keuangan APBD kabupaten/kota); dan 3) pendapatan lain-lain (terdiri atas hibah dan sumbangan dari pihak ketiga yang tidak mengikat dan lain-lain pendapatan desa yang sah).

Terkait dengan nomenklatur jenis-jenis pendapatan desa di atas, perlu dicatat bahwa Permendagri Nomor 113 Tahun 2014 membedakan antara dana desa dengan ADD. Dana desa adalah dana yang bersumber dari APBN yang diperuntukkan bagi desa yang ditransfer melalui APBD kabupaten/kota dan digunakan untuk membiayai penyelenggaraan pemerintahan, pelaksanaan pembangunan, pembinaan kemasyarakatan, dan pemberdayaan masyarakat. Sementara itu, dinyatakan bahwa ADD adalah dana perimbangan yang diterima kabupaten/kota dalam APBD kabupaten/kota setelah dikurangi Dana Alokasi Khusus (DAK). Pembedaan ini sesungguhnya tidak dikenal dalam UU Desa sehingga berpotensi menimbulkan kebingungan dan kesalahpahaman meskipun istilah ADD sebenarnya pernah muncul dan diatur dalam Peraturan Pemerintah Nomor 72 Tahun 2005 Tentang Desa. Membaca pembedaan kedua jenis dana tersebut bermotif politik, yakni sebagai upaya Kemendagri mengamankan dana desa sesuai peruntukannya, yakni untuk pemerintahan, pembangunan, pembinaan, dan pemberdayaan. Dengan demikian, Kemendagri yang menangani urusan pemerintahan masih mempunyai ruang yang luas untuk bekerja karena dana desa tidak melulu dititikberatkan 
pada urusan pembangunan dan pemberdayaan masyarakat sesuai ketentuan Permendes PDTT Nomor 5 Tahun 2015 tentang Penetapan Prioritas Penggunaan Dana Desa. Argumen ini, bagaimanapun, terlalu tipis kekuatannya mengingat Pasal 19 ayat (2) Peraturan Pemerintah Nomor 60 Tahun 2014 sudah mengunci bahwa dana desa memang harus diprioritaskan untuk membiayai pembangunan dan pemberdayaan masyarakat.

Dalam pengertian keseluruhan rupa-rupa pendapatan desa yang dikelola dalam APBDes harus dikelola secara transparan, akuntabel, partisipatif serta dilakukan dengan tertib dan disiplin anggaran (Pasal 2 Permendagri Nomor 113 Tahun 2014). Karena bersumber dari negara, maka pengelolaannya harus mengikuti aturan main yang berlaku terkait pengelolaan dana publik. Dalam Permendagri Nomor 113 Tahun 2014 tentang Pengelolaan Keuangan Desa, ihwal pengelolaan dan desa telah diatur dalam Bab V. Di dalamnya, diatur bahwa pengelolaan dana desa terdiri atas lima hal, yakni perencanaan, pelaksanaan, penatausahaan, pelaporan, dan pertanggungjawaban.

Jika ditilik mulai dari hulu, pengelolaan keuangan desa dimulai dari perencanaan. Pertama kali diadakan musyawarah desa yang diselenggarakan oleh Badan Permusyawaratan Desa (BPD) untuk membahas hal-hal yang sifatnya strategis (lihat Pasal 54 Undang-undang Desa). Kemudian, hasil musyawarah desa berupa perencanaan pembangunan desa ditindaklanjuti dengan musyawarah pembangunan perencanaan desa (musrenbangdes) yang diselenggarakan kepala desa dan perangkatnya. Musrenbangdes inilah yang membahas mengenai Rencana Pembangunan Jangka Menengah Desa (RPJMDes) tiap enam tahun sekali dan Rencana Kerja Pemerintah Desa (RKPDes) serta APBDes tiap setahun sekali. Setelah Raperdes tentang APBDes disepakati bersama oleh kepala desa dan BPD paling lambat bulan Oktober dan hasil evaluasi 
dari bupati/walikota atau camat (yang mendapat delegasi untuk mengevaluasi Raperdes APBDes) menyatakan bahwa Raperdes APBDes tidak bertentangan dengan kepentingan umum dan peraturan perundangundangan yang lebih tinggi, APBDes dapat ditetapkan.

Sebelum desa dapat menerima pencairan dana desa, terlebih dahulu kabupaten/kota harus mengesahkan APBD kabupaten/kota dan peraturan bupati/walikota mengenai tata cara pembagian dan penetapan besaran dana desa (Pasal 17 ayat (1) Peraturan Pemerintah Nomor 60 Tahun 2014 dan Pasal 16 ayat (2) Permenkeu Nomor 93/PMK.07/2015). Sebelum peraturan bupati/walikota itu dibuat, desa menyelesaikan terlebih dahulu APBDes-nya. Keharusan adanya peraturan kepala daerah tersebut sebagai indikasi bahwa kabupaten telah siap untuk menyalurkan dana sesuai peraturan. Per 1 Juli 2015, masih ada 16 kabupaten/ kota yang belum menerima pencairan dana desa tahap pertama senilai Rp 8,306 triliun karena belum menyerahkan persyaratan tersebut, di antaranya Kabupaten Biak Numfor, Kabupaten Merauke, Kabupaten Paniai, Kabupaten Sarmi, Kabupaten Tolikara, Kabupaten Waropen, Kabupaten Supiori, Kabupaten Mamberamo Raya, Kabupaten Mamberamo Tengah, Kabupaten Puncak, Kabupaten Teluk Bintuni, Kabupaten Bekasi, Kabupaten Majalengka, Kota Batu, Kabupaten Kepahiang, dan Kabupaten Konawe (Kompas, 2 Juli 2015) ${ }^{24}$

Penggunaan dana desa dikelola oleh pemerintah desa melalui kuasa kepala desa dan digunakan sesuai RPJMDes, RKPDes, dan

24 Menurut Eko Prasetyanto, keterlambatan penyerahan dokumen tersebut disebabkan karena beberapa hal, di antaranya terlambatnya revisi PP No. 60 tahun 2014 yang memuat pengubahan formula pembagian dana desa sehingga membuat daerah harus menghitung ulang alokasi dana desa untuk daerahnya, sebagian daerah adalah daerah otonom baru, dan bupati atau kepala desanya digantikan oleh pejabat sementara sehingga masih memerlukan waktu untuk memahami peraturan. Sementara itu, Beni Yusnandar dari BPMPD Kabupaten Bekasi mengatakan bahwa daerahnya sengaja tidak mengeluarkan perbup karena menunggu keluarnya Permenkeu No. 93/PMK.07/2015 agar penghitungan yang dilakukan dalam perbup mempunyai landasan hukum yang kokoh dan jelas. Sejak 8 Juli 2015, dana desa sudah masuk ke rekening kabupaten.

64 Naskah Akademik Rancangan Undang-undang Peraturan Daerah Keuangan Desa 
APBDes. Adapun laporan realisasi pelaksanaan APBDes disampaikan kepala desa kepada bupati/walikota berupa laporan semester pertama yang harus disampaikan paling lambat akhir bulan Juli dan laporan semester akhir tahun paling lambat pada akhir bulan Januari tahun berikutnya (Pasal 37 Permendagri Nomor 113 Tahun 2014). Selain pelaporan, kepala desa juga harus menyampaikan laporan pertanggungjawaban realisasi pelaksanaan APBDes dalam bentuk peraturan desa kepada bupati/walikota setiap akhir tahun anggaran (Pasal 38 Permendagri Nomor 113 Tahun 2014).

Lalu, siapa yang mengawasi pengelolaan keuangan desa? Pengawasan memegang peranan penting dalam memastikan agar pengelolaan dana desa berjalan dengan akuntabel, transparan, dan partisipatif demi kemaslahatan umum masyarakat desa. Pengawasan yang ketat, terkontrol, profesional, dan berintegritas menjadi prasyarat penting. Pengelolaan keuangan desa sesungguhnya diawasi secara berlapis oleh banyak pihak. Pada Pasal 44 Permendagri Nomor 113 Tahun 2014 disebutkan bahwa "Pemerintah Kabupaten/Kota membina dan mengawasi pelaksanaan pengelolaan keuangan desa." Dalam hal ini, Inspektorat Daerah akan berperan penting sebagai leading institution inwal pengawasan pengelolaan keuangan desa. Sementara di tingkat pusat, BPK dan Badan Pengawasan Keuangan dan Pembangunan (BPKP) juga akan mengawasi pengelolaan keuangan desa secara sampling. Pengelolaan keuangan desa menjadi ranah pengawasan mereka karena keuangan desa adalah uang negara yang bersumber dari APBN dan APBD sehingga pengelolaannya harus dipertanggungjawabkan sesuai dengan kaidah yang berlaku. 


\section{BAB V \\ JANGKAUAN, ARAH PENGATURAN, DAN RUANG LINGKUP MATERI MUATAN UNDANG-UNDANG}

\section{A. Sasaran}

Kehadiran aturan tentang keuangan desa adalah untuk menghadirkan masyarakat dalam proses pembangunan yang lebih tertata dan akuntabel, untuk mengatur hal tersebut Pengaturan pengelolaan keuangan desa harus dimuat dalam Peraturan Daerah untuk memberikan kepastian hukum terhadap pemerintahan desa sebagai pelaksana dari amanat peraturan yang dilaksanakan.

B. Jangkauan dan Arah Pengaturan

Rancangan Peraturan Daerah tentang Keuangan Desa mencoba untuk mempertegas peran dan fungsi dari pemerintah desa dalam penyelenggaraan Pemerintahan Desa terkait dengan pengelolaan keuangan. Kedepannya yang coba kita bangun adalah bagaimana melalui Peraturan Daerah ini aspirasi masyarakat dapat tersalurkan melalui aturan tentang pengelolaan keuangan desa. Oleh karena itu pengaturan tentang keuangan desa, yaitu susunan fungsi, kedudukan dan kewenangan adalah menjadi penting untuk menjawab tantangan kedepan dalam mendorong pemerintah desa dalam mewujudkan tata kelola pemerintahan yang baik.

\section{Ruang Lingkup Muatan Materi Undang-Undang}

Ketentuan Umum

ketentuan umum berisi :

a. Batasan pengertian atau defenisi

b. Singkatan atau akronim yang dituangkan dalam batasan pengertian atau defenisi

c. Hal-hal lain yang bersifat umum yang berlaku bagi pasal atau beberapa pasal berikutnya antara lain ketentuan yang mencerminkan asas, maksud dan tujuan tanpa dirumuskan tersendiri dalam pasal atau bab. 
- Daerah adalah Daerah kabupaten ......

- Pemerintah Daerah adalah Bupati dan Perangkat daerah sebagai unsur Penyelengara Pemerintahan Daerah.

- Bupati adalah Bupati ......

- Sekertaris Daerah adalah sekertaris Daerah Kabupaten ......

- Dinas Pemberdayaan Masyarakat Dan Pemerintah Desa adalah Dinas Pemberdayaan Masyarakat Dan Pemerintah Desa Kabupaten ......

- Pemerintah Desa adalah Kepala Desa dibantu Perangkat Desa sebagai Unsur Penyelenggara Pemerintahan Desa yang diberada di Kabupaten .....;

- Kepala Desa adalah pemimpin desa yang dipilih langsung oleh penduduk desa yang bersangkutan;

- Perangkat Desa adalah unsur pembantu kepala desa yang terdiri dari Sekretariat Desa, pelaksana kewilayahan dan pelaksana teknis

- Keuangan Desa adalah semua hak dan kewajiban desa yang dapat dinilai dengan uang serta segala sesuatu berupa uang dan barang yang berhubungan dengan pelaksanaan hak dan kewajiban desa.

- Anggaran pendapatan dan Belanja Desa yang selanjutnya disingkat APBDesa adalah rencana keuangan tahunan pemerintahan desa ;

- Pedoman Penyusunan APBDesa adalah Pokok-Pokok kebijakan yang harus dipedomani dan dilaksankan oleh Pemerintah Desa dalam penyusunan dan penetapan APBDesa. 
Materi Muatan

1. Pelaksanaan

Pelaksanaan pengelolaan keuangan desa di laksanakan dalam beberapa tahap diantaranya :

a. Perencanaan

Pada tahap ini dilaksanakan penyusunan dan penetapan RPJMDesa dan RKPDesa, penyusunan, evaluasi, penetapan, rancangan Peraturan Desa tentang APBDesa, perubahan Peraturan Desa tentang APBDesa, pendapatan Desa, belanja Desa,

b. Pelaksanaan

Semua penerimaan dan pengeluaran desa dalam rangka pelaksanaan kewenangan desa dilaksanakan melalui rekening kas desa

c. Penatausahaan

Pihak yang menjadi penguasa pemegang pengelolaan dalam hal ini adalah Kepala Desa.

d. Pelaporan dan Pertanggungjawaban

Laporan pelaksanaan APBDesa dilaporkan kepada Bupati melalui Camat dengan tembusan kepada Inspektorat Daerah

\section{Pengawasan}

Pengawasan dan pembinaan dilakukan oleh Bupati dan Camat. Pengawasan dilakukan dengan cara memantau dan mengawasi jadwal perencanaan dan pelaksanaan pembangunan desa. dalam hal terjadi keterlambatan perencanaan dan pelaksanaan pembangunan desa sebagai akibat dari ketidakmampuan dan atau kelalaian pemerintah desa, Bupati melakukan penerbitan surat peringatan kepada Kepala Desa atau meberikan pembinaan dan pendampingan kepada desa. 
3. Evaluasi

Untuk mengetahui keberhasilan pengelolaan keuangan desa oleh pemerintah desa maka akan dievaluasi oleh pemerintah Kabupaten .... dalam hal ini Bupati, camat dan Inspektorat Derah atau pembentukan lembaga khusus untuk itu yang akan diatur dengan Peraturan Bupati

4. Pembiayaan

Biaya pelaksanaan Peraturan Daerah tentang Keuangan Desa dibebankan kepada Anggaran Pendapatan dan Belanja Daerah Kabupaten ..... atau sumber-sumber lain yang sah dan tidak mengikat

\section{Ketentuan Sanksi}

Sanksi yang diberikan kepada pihak-pihak yang terlibat dalam keuangan Desa yang dengan sengaja atau terencana untuk melanggar ketentuan yang telah diatur maka diberikan sanksi administratif dan sosial sebagaimana bentuknya.

Sanski yang diberikan pada setiap individu bisa berupa pembinaan dan seterusnya hingga pada sanksi administrativ yang diberikan oleh Pemerintah Daerah Kabupaten .....

6. Ketentuan Penutup

Pada saat Peraturan Daerah ini mulai berlaku, semua peraturan perundang-undangan yang berkaitan dengan pengelolaan keuangan Desa dinyatakan masih tetap berlaku sepanjang tidak bertentangan dengan ketentuan dalam Peraturan Daerah ini. 


\section{BAB VI}

\section{PENUTUP}

\section{A. Kesimpulan}

Pemerintah dan BPD merupakan penyelenggaraan pemerintahan desa yang mempunyai peran yang sangat penting dalam penyelenggaraan pemerintahan desa. Dengan adanya Undang-undang Nomor 6 Tahun 2014 ini dalam pelaksanaannya dituntut untuk mencerminkan otonomi asli desa, demokratisasi, partisipasi dan keanekaragaman sebagai landasan pemikiran desa. Pemerintah desa adalah Kepala Desa dan Perangkat Desa sebagai unsur penyelenggara pemerintahan desa. Sedangkan perangkat desa terdiri dari sekretariat desa yang dipimpin oleh sekretaris desa, pelaksana teknis lapangan dan unsur kewilayahan yang disesuaikan dengan kebutuhan dan kondisi wilayah setempat.

Konsep keuangan desa hampir sama dengan konsep keuangan negara, dilakukan melalui mekanisme Anggaran Pendapatan dan Belanja Desa, yang didalamnya terdiri atas bagian pendapatan, belanja, dan pembiayaan desa, yang dilaksanakan oleh Kepala Desa dan aparatnya yang dimusyawarahkan secara bersama dengan Badan Permusyawaratan Desa. Pengelolaan keuangan desa menimbulkan implikasi yuridis bagi Kepala Desa dan Badan Permusyawaratan Desa untuk mampu menyusun, mengesahkan, melaksanakan, mengawasi dan mempertanggungjawabkan pengelolaan keuangan desa. Jika terjadi kealpaan atau kesengajaan, maka menimbulkan pertanggungjawaban baik secara administratif maupun pidana. Bagi Pemerintah Kabupaten/Kota berkewajiban untuk mengalokasikan anggaran bagi keuangan desa, serta melakukan pembinaan dan pengawasan. 


\section{B. Rekomendasi}

Sebagai rekomendasi untuk mencegah pengelolaan dana desa dapat dilakukan dengan baik dan berintegritas, maka diperlukan pencermatan atas poin-poin berikut. Pertama, berbagai peraturan yang mengatur tentang dana desa mulai dari tingkat Undangundang, Peraturan Pemerintah, Peraturan Menteri, Peraturan Daerah dan Perbup/Perwal harus dicek keselarasan dan koherensinya. Jangan sampai ada peraturan yang tumpang tindih dan bertentangan dan jangan sampai ada peraturan yang substansinya bukan menjadi urusan dari pihak yang mengeluarkan peraturan. Dengan demikian, tidak akan ada cerita pelanggaran pengelolaan keuangan desa akibat peraturan yang bertentangan atau tidak jelas. Lebih jauh, peraturan tersebut juga hendaknya dievaluasi agar jangan terlalu restriktif dan kaku (dengan tanpa mengorbankan prinsip-prinsip tata kelola yang baik) karena itu hanya akan memperluas birokratisasi dan ujung-ujungnya ruang gerak desa menjadi terbatas. Kemungkinan untuk perubahan atau revisi juga harus dibuka setiap saat sebagai respons atas feedback dan dinamika yang terjadi di lapangan, atau manakala peraturan yang ada di dalamnya tidak sesuai dengan aspirasi otentik masyarakat desa 


\section{LAMPIRAN KONSEP AWAL RANCANGAN UNDANG-UNDANG}

Konsep Awal Undang-Undang yang terdiri dari pasal-pasal yang diusulkan dengan didasarkan pada uraian akademik.

Konsiderans :

- bahwa desa dalam mengatur dan mengurus kepentingan masyarakat berperan mewujudkan cita-cita kemerdekaan berdasarkan Undang-Undang Dasar Negara Republik Indonesia Tahun 1945 perlu dilindungi dan diberdayakan agar menjadi kuat, maju, mandiri, dan demokratis sehingga dapat menciptakan landasan yang kukuh dalam melaksanakan pemerintahan dan pembangunan menuju masyarakat yang adil, makmur, dan sejahtera;

- bahwa dengan adanya perubahan regulasi mengenai pengelolaan keuangan desa, maka agar pengelolaan keuangan desa dapat terarah dan berjalan sesuai dengan ketentuan peraturan perundang undangan, diperlukan pedoman dalam mengelola keuangan desa;

- bahwa berdasarkan pertimbangan sebagaimana dimaksud dalam huruf a dan huruf b perlu menetapkan Peraturan Daerah tentang Keuangan Desa;

Dasar Hukum : 


\section{।}

- Undang - Undang Nomor 17 Tahun 2003 tentang Keuangan Negara (Lembaran Negara Republik Indonesia Tahun 2003 Nomor 47,Tambahan Lembaran Negara Republik Indonesia Nomor 4286);

- Undang-Undang Nomor 1 Tahun 2004 tentang Perbendaharaan Negara (Lembaran Negara Tahun 2004 Nomor 5, Tambahan Lembaran Negara Nomor 4355);

- Undang-Undang Nomor 15 Tahun 2004 tentang Pemeriksaan Pengelolaan dan Tanggungjawab Keuangan Negara (Lembaran Negara Tahun 2004 Nomor 66, Tambahan Lembaran Negara Nomor 4400);

- Undang-Undang Nomor 33 Tahun 2004 tentang Perimbangan Keuangan Antara Pemerintah Pusat dan Pemerintahan Daerah (Lembaran Negara Republik Indonesia Tahun 2004 Nomor 126, Tambahan Lembaran Negara Republik Indonesia Nomor 4438);

- Undang-Undang Nomor 12 tahun 2011 tentang Pembentukan Peraturan Perundang - undangan (Lembaran Negara Tahun 2011 Nomor 82, Tambahan Lembaran Negara Nomor 5234);

- Undang-Undang Nomor 6 Tahun 2014 tentang Desa (Lembaran Negara Republik Indonesia Tahun 2014 Nomor 7, Tambahan Lembaran Negara Republik Indonesia Nomor 5495);

- Undang-Undang Nomor 23 Tahun 2014 tentang Pemerintahan Daerah (Lembaran Negara Republik Indonesia Tahun 2014 Nomor 244, Tambahan Lembaran Negara Republik Indonesia Nomor 5587) sebagaimana telah diubah beberapakali terakhir dengan UndangUndang Nomor 9 Tahun 2015 tentang Perubahan Kedua Atas Undang-Undang Nomor 23 Tahun 2014 tentang Pemerintahan Daerah (Lembaran Negara Republik Indonesia Tahun 2015 Nomor 58, Tambahan Lembaran Negara Republik Indonesia Nomor 5679); 


\section{।}

- Peraturan Pemerintah Nomor 58 Tahun 2005 tentang Pengelolaan Keuangan Daerah (Lembaran Negara Tahun 2005 Nomor 140, Tambahan Lembaran Negara Republik Indonesia Nomor 4578);

- Peraturan Pemerintah Nomor 6 Tahun 2006 tentang Pengelolaan Barang milik Negara/Daerah (Lembaran Negara Tahun 2006 Nomor 20, Tambahan Lembaran Negara Republik Indonesia Nomor 4609);

- Peraturan Pemerintah Nomor 71 Tahun 2010 tentang Standar Akuntansi Pemerintahan (Lembaran Negara Republik Indonesia Tahun 2010 Nomor 123, Tambahan Lembaran Negara Republik Indonesia Nomor 5165);

- Peraturan Pemerintah Nomor 47 Tahun 2015 Tentang Perubahan Atas Peraturan Pemerintah Nomor 43 Tahun 2014 tentang Peraturan Pelaksanaan Undang-Undang Nomor 6 Tahun 2014 tentang Desa (Lembaran Negara Republik Indonesia Tahun 2015 Nomor 157, Tambahan Lembaran Negara Republik Indonesia Nomor 5717);

- Peraturan Pemerintah Nomor 60 Tahun 2014 tentang Dana Desa Yang Bersumber Dari Anggaran Pendapatan dan Belanja Negara (Lembaran Negara Republik Indonesia Tahun 2014 Nomor 168, Tambahan Lembaran Negara Republik Indonesia Nomor 5558) sebagaimana telah diubah beberapakali terakhir dengan Peraturan Pemerintah Nomor 8 Tahun 2016 tentang Perubahan Kedua Atas Peraturan Pemerintah Nomor 60 Tahun 2014 tentang Dana Desa Yang Bersumber Dari Anggaran Pendapatan dan Belanja Negara (Lembaran Negara Republik Indonesia Tahun 2016 Nomor 57, Tambahan Lembaran Negara Republik Indonesia Nomor 5864);

- Peraturan Menteri Dalam Negeri Nomor 113 Tahun 2014 Tentang Pedoman Pengelolaan Keuangan Desa(Berita Negara Republik Indonesia Tahun 2014 Nomor 2093,)

- Peraturan Menteri Desa, Pembangunan Daerah Tertinggal, Dan Transmigarsi Rebuplik Indonesia Nomor 01 Tahun 2015 Tentang 
Pedoman Kewenangan Berdasarkan Hak Asal Usul Dan Kewenangan Lokal Bersekala Desa (Berita Negara Republik Indonesia Tahun 2015 Nomor 158)

Ketentuan Umum :

- Daerah adalah Daerah kabupaten ......

- Pemerintah Daerah adalah Bupati dan Perangkat daerah sebagai unsur Penyelengara Pemerintahan Daerah.

- Bupati adalah Bupati ......

- Sekertaris Daerah adalah sekertaris Daerah Kabupaten ......

- Dinas Pemberdayaan Masyarakat Dan Pemerintah Desa adalah Dinas Pemberdayaan Masyarakat Dan Pemerintah Desa Kabupaten ......

- Pemerintah Desa adalah Kepala Desa dibantu Perangkat Desa sebagai Unsur Penyelenggara Pemerintahan Desa yang diberada di Kabupaten .....;

- Kepala Desa adalah pemimpin desa yang dipilih langsung oleh penduduk desa yang bersangkutan;

- Perangkat Desa adalah unsur pembantu kepala desa yang terdiri dari Sekretariat Desa, pelaksana kewilayahan dan pelaksana teknis

- Keuangan Desa adalah semua hak dan kewajiban desa yang dapat dinilai dengan uang serta segala sesuatu berupa uang dan barang yang berhubungan dengan pelaksanaan hak dan kewajiban desa.

- Anggaran pendapatan dan Belanja Desa yang selanjutnya disingkat APBDesa adalah rencana keuangan tahunan pemerintahan desa;

- Pedoman Penyusunan APBDesa adalah Pokok-Pokok kebijakan yang harus dipedomani dan dilaksankan oleh Pemerintah Desa dalam penyusunan dan penetapan APBDesa. 
Materi :

Maksud, Tujuan Dan Sasaran

Maksud dari Peraturan Daerah ini untuk memberikan kepastian hukum bagi pemerintah desa sebagai pelaksana dalam pengelolaan keuangan desa

Tujuan Khusus

Untuk memberikan gambaran tentang fungsi dan tugas dari pemerintah desa terkait dengan proses pengelolaan keuangan desa

Tujuan Umum

Untuk melibatkan masyarakat dalam pembangunan desa sebagai pengontrol jalannya pembangunan melalui penggunaan dan pengelolaan keuangan desa

\section{Sasaran}

Sasaran dalam Peraturan Daerah keuangan desa adalah seluruh masyarakat yang berdomosili diwilayah Kabupaten .....

\section{Penilaian}

Untuk mengukur dan mengetahui keberhasilan pengelolaan keuangan desa dapat diadakan penilaian oleh lembaga yang ditentukan oleh pemerintah daerah Kabupaten ..... dalam hal ini lembaga yang akan diatur dengan peraturan dan surat keputusan Bupati.

\section{Pelaksana}

1. Pemerintah Desa melaksanakan perencanaan, penyusunan dan penetapan RPJMDesa dan RKPDesa 
2. Kepala Desa melaksanakan :

a. Pencermatan pagu indikatif desa

b. Menyampaikan rancangan Peraturan Desa tentang APBDesa kepada BPD untuk dibahasa dan disepakati bersama

c. Menyampaikan rancangan Peraturan Desa tentang APBDesa yang telah disepakati kepada Bupati melalui Camat untuk dievaluasi

d. Menindaklanjuti hasil evaluasi Bupati apabila dalam hasil evaluasi dinyatakan tidakl sesuai dengan ketentuan

e. Menetapkan Rancangan Peraturan Desa tentang APBDesa

f. Menyampaikan laporan realisasi pelaksanaan dan pertanggungjawaban realisasi pelaksanaan APBDesa kepada Bupati melalui Camat

3. Camat

a. Menfasilitasi penyusunan Peraturan Desa terkait keuangan desa

b. Memfasilitasi pengelolaan keuangan dan aset desa serta tertib admistrasi dibidang keuangan desa

c. Mengawasi pelaksanaan APBDesa

d. Memfasilitasi permasalahan yang timbul dalam pelaksanaan APBDesa dan keuangan desa

4. Bupati

Memberikan pembinaan dan pengawasan dengan cara memantau dan menagawasi jadwal perencanaan dan pelaksanaan pembanguan desa, menerima, mempelajari dan memberikan bimbingan teknis terhadap laporan realisasi pelakasnaan APBDesa, dan mengevaluasi perkembangan kemajauan pembanguan desa. 
Pembiayaan

Keseluruhan pembiayaan kegiatan Peraturan Daerah Keungan Desa diambil dari sumber anggaran pendapatan dan belanja daerah serta sumber-sumber pendanaan lainnya yang sah dan tidak mengikat.

Sanksi

Sanksi yang diberikan kepada pihak-pihak yang terlibat dalam keuangan Desa yang dengan sengaja atau terencana untuk melanggar ketentuan yang telah diatur maka diberikan sanksi administratif dan sosial sebagaimana bentuknya.

Sanski yang diberikan pada setiap individu bisa berupa pembinaan dan seterusnya hingga pada sanksi administratif yang diberikan oleh Pemerintah Daerah Kabupaten ..... 


\section{Referensi:}

Peraturan Menteri Dalam Negeri Republik Indonesia Nomor 113 Tahun 2014 Tentang Pengelolaan Keuangan Desa

Peraturan Menteri Desa, Pembangunan Daerah Tertinggal, Dan Transmigrasi Republik Indonesia Nomor 22 Tahun 2016 Tentang Penetapan Prioritas Penggunaan Dana Desa Tahun 2017

Peraturan Pemerintah Republik Indonesia Nomor 22 Tahun 2015 Tentang Perubahan Atas Peraturan Pemerintah Nomor 60 Tahun 2014 Tentang Dana Desa Yang Bersumber Dari Anggaran Pendapatan Dan Belanja Negara

Peraturan Pemerintah Republik Indonesia Nomor 43 Tahun 2014 Tentang Peraturan Pelaksanaan Undang-Undang Nomor 6 Tahun 2014 Tentang Desa

Peraturan Pemerintah Republik Indonesia Nomor 47 Tahun 2015 Tentang Perubahan Atas Peraturan Pemerintah Nomor 43 Tahun 2014 Tentang Peraturan Pelaksanaan Undang-undang Nomor 6 Tahun 2014 Tentang Desa

Peraturan Pemerintah Republik Indonesia Nomor 60 Tahun 2014 Tentang Dana Desa Yang Bersumber Dari Anggaran Pendapatan Dan Belanja Negara

Umanailo, M Chairul Basrun. 2018. proses modernisasi dan pergeseran okupasi. researchgate.net/publication/323935634_proses_modernisasi_dan_pergesera n_okupasi. DOI: 10.13140/RG.2.2.19671.78241.

Umanailo, M. C B. 2017. "MASYARAKAT BURU DALAM PERSPEKTIF KONTEMPORER.” Open Science Framework. December 10. doi:10.17605/OSF.IO/KZGX3

Umanailo, M. C. B. (2017, December 11). KAJIAN DAN ANALISIS SOSIOLOGI. http://doi.org/10.17605/OSF.IO/PV24F.

Umanailo, M. C. B. (2017, December 11). SOSIOLOGI HUKUM. http://doi.org/10.17605/OSF.IO/KHFNU

Umanailo, M. C. B. (2018, March 17). Ilmu Sosial Budaya Dasar. http://doi.org/10.17605/OSF.IO/4HPWC.

Undang-Undang Dasar 1945

Undang-Undang Republik Indonesia Nomor 12 Tahun 2011 Tentang Pembentukan Peraturan Perundang-Undangan

Undang-Undang Republik Indonesia Nomor 23 Tahun 2014 Tentang Pemerintahan Daerah

Undang-Undang Republik Indonesia Nomor 6 Tahun 2014 Tentang Desa 